\title{
معوقات تدريب معلمات رياض الأطفال الغير متخصصات أثناء الخدمة من وجهة نظر المعلمات والموجهات الفير متفيات
}

\section{إعـــداد \\ الباحثة / إجلال سعيد عحم الزيات'}

\section{إشــــــــ}

أ.م.د/هبة حسين طلعت

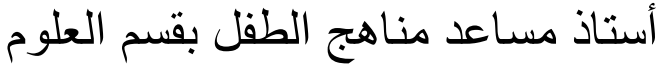
التربوية ـ كلية التربية للطفولة المبكة لفيكرة

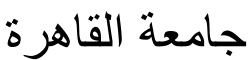

أ.د /مني محمد علي جاد الطني

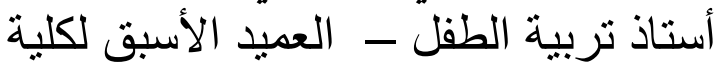
كلية التربية للطفولة المبكرة

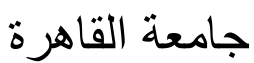

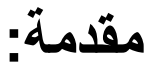

يتسم العصر الحالي بالتغير الكمي والكيفي السريع في كافة مجالات المعرفة وميع هذا التزايد زاد الاهتمام بإعداد المعلمات في بر امج الإعداد وتدريبهن ،حيث يسهم تدريب المعلمات أثناء الخدمة في رفع مستوي كفاءتهن وتحسين أدائهن و لا ينظر إلـي التدريب علي أنه محاولـة لمعالجة أوجه القصور أو الضعف في الإعداد قبل الخدمة فحسب ولكن ينظر إليه علي أنها يؤدي تجديـد معـارف المعلمـين وصـقل خبـر اتهم، ومهـار اتهم المهنيـة بهـدف تحسين فاعليـة العمليـة التعليمية. ويعد التـدريب بشكل عـام وظيفة إداريـة رئيسية ومستمرة وتعد مـن واجبـات الإدارة

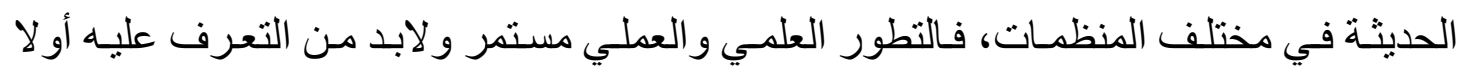
بأول، ففي المجال الإداري استحدثت أساليب للبرمجة و الكمبيوتر ونظم المعلومات وتحليل النظم وبحوث العمليات والمهار ات السلوكية ثم إن نوعية القوي العاملة اختلفت كثير ا عن ذي قبل مما

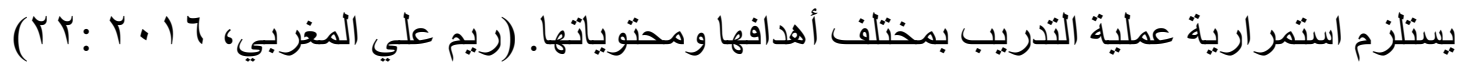


كمـا أن التدريب عملية ضرورية لمو اكبة المستجدات، وينطلق من تحديد الاحتياجات التدريبيـة و الفئـات المستهدفة، و الأهداف المنشـودة المخططـة ،ثم ينتقل إلـي تصـيم البـر امج التدريبية التي تلبي هذه الاحتياجات، وبعد ذللك يبدأ تنفيذ هذه البرامج وتتنهي عملية التدريب إلي تقويم البر امج التدريية لتحديد المخرجات التي تمخضت عن عملية التدريب، و الإستفادة من هذا التقويم في تخطيط البر امج التدريبية اللاحقة، وترتبط هذه العملية بالمعلم أثناء الخدمة بعد انتهاء

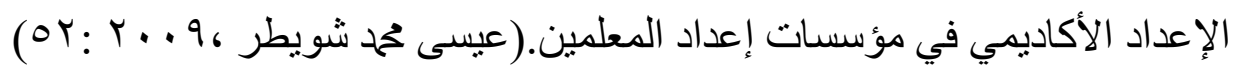
وينال تدريب المعلمين أثناء الخدمة اهتمامـا بالغاً في معظم دول العالم، ففي الولايات المتحدة الأمريكية تجد اهتماأ كبير اً ببر امج التدريب وتطور ها، وأن ما ينفق من أموال علي هذه

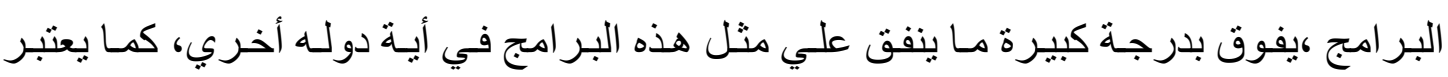

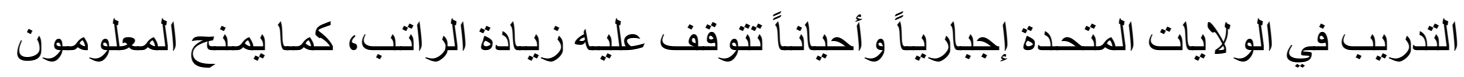
إجـاز ات در اسـية لمـدة عـام، يلتحقون بهـا بالدر اسـات التـي تعـدها الجامعـات للمعلمين.(جمـال

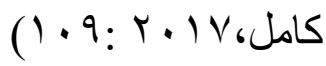

في المقابل نجد أن تدريب المعلمين أثناء الخدمة بصفة عامـة ومعلمـات ريـاض الأطفال غير المتخصصات في الدول العربية بصفة خاصـة الأقل تقدما منها يعاني من معوقات عديدة أثرت علي النتائج المتوقعة للتدريب أو عدم تحقيق أهدافه نتيجـة لسوء أسلوب تحديدها أو الفشل فئل في الوصول إليها بسبب وجود بعض المعوقات التي أدت إلي ضعف نتائج أو أثر التدريب يعمل البحث الحالي علي التعرف عليها.

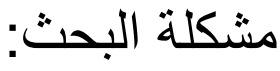

إن إعداد المعلم قبل الخدمة لا يوفر له سوي الأساس الذي يساعده علي البدء في ممارسـة

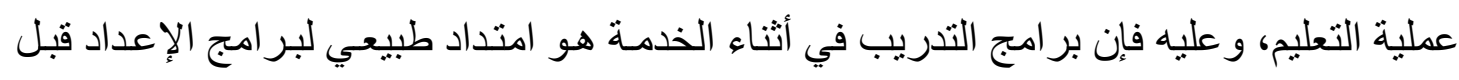

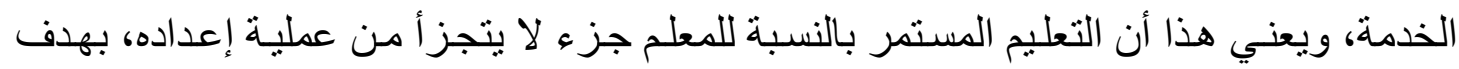

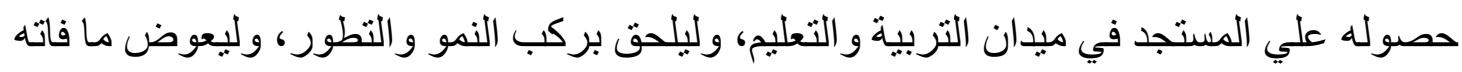
من نقص في أثناء إعداده قبل الخدمة. فجودة بر امج إعداد معلمة رياض الأطفال الغير متخصصـات قبل الخدمة مهمـا كانت فإنها لا تسنطيع أن تزودها بحلول لكل المشكلات التي سوف تو اجهها في مو اقع العمل الفعلية 
ولهذا وجب تدريبها ببر امج تدريب مستمرة لكي تزودها هذه البر امج بمهار ات التعلم الذاتي لكي تو اجـه مـا يمكـن أن تتعـرض لـه ولكي تتمـي مهـار ات التنميـة المهنبـة لـديها. (ياسـر العـاجز

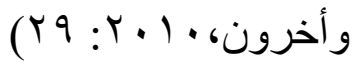
وقد قامت الباحثة بعمل در اسـة إستطلاعية للمسـاعدة في تحديد مشكلة البحث و التعرف علي معوقـات تدريب معلمـات ريـاض الأطفـال الغير متخصصـات وكـان مـن أهداف الدر اسـة الإستطلاعية التعرف علي الطر ائق التعليميـة المستخدمة وكيفية إعداد بيئة التعلم وكيفيـة إعداد وتنظيم محتوي الأنشطة وكيفيـة إختيـار و إستخدام الوسـائل التعليميـة وتكنولوجيـا التعليم وكيفيـة اختبار وتطبيق طرق التقويم المناسبة للاطفال من قبل المعلمات ومعرفة البر امج التدريبية التي قدمت لهن أثناء الخدمة ومدس استفادتهن من هذه البر امج وكذللك المعوقات التي واجهنهن أنتاء هذه البر امج التدريبية ومحاولة علاجها بما بسمح للتدريب من تحقيق أهدافه دون معوقات أو بحد أدني منها، و هذا سيزيد من كفاءة وفعالية البر امج التدريبية، بل إن رصد هذه المشكلات و التعرف عليها سيسـاهم في تجنب الوقوع فيهـا أو منـع حدوثها في المسـقبل، فالوقايـة خيـر مـن العـلاج وتكونت العينة الاستطلاعة من ( • ()) معلمة وموجهة رياض أطفال مكونة من (0 ( ) معلمة غير متخصصــة موزعـة في عدة مر اكز مختلفـة مـن محافظـة المنوفيـة ويعملن في القطـاع الخـاص ويمتلكن خبره في التعامل مع الأطفال ما بين(r ــ) سنوات (0 ( )موجهة لرياض أطفال وتمتلكن خبـره مـا بـين (0_م) سـنو ات، وتكونــت الإسـتبانه الموجهـة لمعلمـات ريـاض الأطفـال الغيـر متخصصات و الموجهات رياض الأطفال بمحافظة المنوفية من مجمو عة من البنود بهدف معرفة المعوقات التي تو اجه المعلمات وكذللك مسـاعدة المعلمات الغير متخصصسات التي أنخرطت في مهنة التعليم دون تأهيل سابق و التي يعوز ها أن تلم بالجوانب المعرفية و المهاريـة الكافيـة لتعامل مع الأطفال و إتاحـة فرص التجديد والإبتكار للمعلمـات حيث تخلق البر امج التدريبيـة جو لتقبـل أفكار المعلمات الجديدة وتشجيعها كما تتيح الفرصـة للمعلمات غير المتخصصسات لكي يختبروا جدوي أفكـار هم الإبتكاريـة ومردودهـا العلمـي و إذا ثبـت صـلاحيتها يـتم نشـر ها بـين المعلمـات وجاءت نتائج الدر اسـة الإستطلاعية التي قامت بإجر ائهـا الباحثة قلـة البر امج التدريبيـة المقدمـه لهـؤلاء المعلمـات الغيـر متخصصـات ، إلـي وجـود معوقـات أثتــاء تـدريب المعلمـات الغيـر متخصصات و الذي كان له أثز كبير علي النتائج المتوقعة من التدريب وكذلك عدم تحقيق أهداف التـدريب وذلك نتيجـة لسـوء أسـلوب تحديدها أو الفشـل في الوصـول إليهـا بسبب وجـود بعض 
المعوقات التي أدت إلي ضعف نتائج التدريب المقدم لهن ومنها بر امج التدريب المقدمة لهن قديمة لا تصلح لإعداد معلمات المستقبل، نظام التدريب يفتقد إلي وجود بر امج عملية وتطبيقيه وورش عمل ولقاءات مباشرة مكمله له، التدريب غير شـامل ويركز علي الجانب التقني ويهمل الجانب الإنساني الأخلاقي، شكلية تقويم البر امج و إفتقار ها إلي المتابعة بعد الدورات و عدم تو افر قاعدة بيانات دقيقة توضح البر امج التدريبية ونو عها ،تو اضع الإمكانات جعلت البر امج قصيرة المدي لا تحقق الغرض منهـا، وعدم تـو افر كو ادر مدربـة متفر غـة بدرجـة كافيـة تضـلع بتنفيذ البر امج التدرييية مما ينتج عنه عدم إحداث التغير ات المطلوبة في مهار ات المعلمات. ومن خلال العرض السابق نجد أن هناك نقص في الأحتياجات التدريبية المقدمة لمعلمات ريـاض الأطفـال و التي تعنى بالجانب التكنولوجي خاصـة في عصـرنا الر اهن نظر اً لسـر عة التطـور التكنولـوجي وتقنيـات التعليم و التعلم، مدـا يسـتدعي مو اصـلة إكسـاب معلمـات ريـاض الأطفال المهار ات التقنية، لكون هذه المرحلـة من أهم مر احل بنـاء الأجيال، لذللك يمكن تحديد مشكلة البحث في التالي: أسئلة البحث: - n: يحاول البحث الحالي الإجابة علي السؤال الرئيسي التالي: - ما معوقات تدريب معلمات ريـاض الأطفال الغير متخصصسات أثناء الخدمـة مـن وجهة نظر المعلمات و الموجهات. ويتفرع من هذا السؤ ال التساؤلات الفرعية التالية: ـ ـ ما الإتجاهات الحديثة في بر امج تدريب معلمات رياض الأطفال غير المتخصصات أثناء الخدمة؟ Y - ما و اقع سياسة بر امج تدريب معلمـات ريـاض الأطفال غير المتخصصـات أثنـاء الخدمـة في مصر؟

"ـ ما معوقات تدريب معلمات رياض الأطفال غير المتخصصـات أثناء الخدمـة من وجهة نظر المعلمات والموجهات؟ 


$$
\text { أهداف البحث: : n }
$$

- التعرف علي معوقات تدريب معلمات رياض الأطفال الغير متخصصـات أثناء الخدمـة من وجهة نظر المعلمات والموجهات.

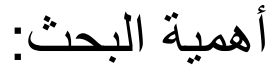
تكمن أهمية البحث في:

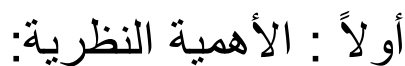

1- تسهم في تطوير الأداء الوظيفي لمعلمات رياض الأطفال الغير متخصصـات من خلال التعرف علي أرائهم عن البرامج التدريبية التي تقدها وزارة التربية والتعليم في مصر. r- إلقاء الضـوء علي معوقات تدريب معلمـات ريـاض الأطفال غير المتخصصـات أثنـاء الخدمة و إثراء المكتبة العربية في هذا المجال. rــ العمل علي تحسين البرامج التدرييية والإسهام في تطوير ها وتوجيهـا نحو تحقيق فهم أفضل للأدوار الجديدة للمعلمات.

ع ـ العهل علـي تقديم اسـتجابات موضـو عية لمر اجعـة وتطـوير بـر امج متقدمـة ومنطورة

$$
\text { للتندريب. }
$$

0ـ تشخيص و اقع بر امج تدريب معلمـات ريـاض الأطفال غير المتخصصـات في مصر

$$
\text { للوقوف علي جو انب القوة و الضعف فيها. }
$$

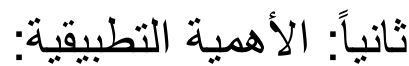

1ـ مساعدة المسئولين في وزارة التربية و التعليم و القائمين علي بر امج التدريب و الإثر اف حيث إن إطلاع المسئولين علي معوقات بر امج تدريب المعلمـات غير المتخصصـات قد

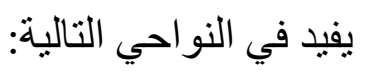

- العمل علي إيجاد الحلول لمعوقات تدريب معلمات رياض الأطفال الغير متخصصـات

$$
\text { أثناء الخدمة. }
$$

- الوقوف علي الجو انب الإيجابية وتدعيمها و أما السلبية فتساعد علي تلافيها. 
r- مساعدة مخططي برامج تدريب معلمات رياض الأطفال الغير متخصصات في مجالات تخطيط وتنفيذ وتقويم وتطوير ومتابعة بر امج التدريب، مما يجعل أثر ها فعال في الإسهام في تطوير وتحسين العملية التربوية.

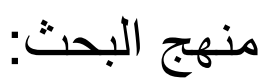

اتبعت الباحثة المنهج الوصفي التحليلي و الذي يقوم علي مجموعة من الإجر اءات البحثية بهدف وصف و اقع تدريب معلمات رياض الأطفال الغير متخصصـات أثناء الخدمة في مصر و من ثم جمـع البيانـات و الحقائق و المعلومـات وتصنيفها وتحلبلها لاستخلاص النتائج المتعلقة. بمعوقـات تـدريب معلمـات ريـاض الأطفـال غي المتخصصـات أثنـاء الخدمـة مـن وجهـة نظـر المعلمات و الموجهات بالإضافة إلي بعض الأساليب الإحصائية لمعالجة نتائج الدر اسة. مجتمع البحث و عينته: يتكون المجتمع الأصلي للبحث من جميع معلمات رياض الأطفال الغير متخصصـات و الموجهات ريـاض الأطفال المتو افرة في مديريـة التربيـة و التعليم إدارة شبين الكوم التعليميـة بمحافظة المنوفية و عددهم ( • ) معلمة غير متخصصة،(70) موجهة رياض أطفال.

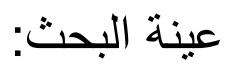

تكونت عينة البحث من ( • ؟) معلمة غير متخصصة وموجهة بمرحلة رياض الأطفال من محافظة المنوفية مقسمة إلي(Y0) معلمة (10 (10) موجهة.

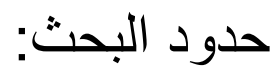

لقد تم تنفيذ البحث ضمن الحدود التالية:

1ـ الحدود البثرية : معلمـات وموجهات ريـاض الأطفال الغير متخصصـات بمحافظـة

$$
\text { المنوفية( عينة البحث) }
$$

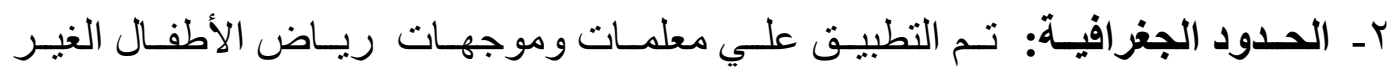
متخصصات بمحافظة المنوفية .

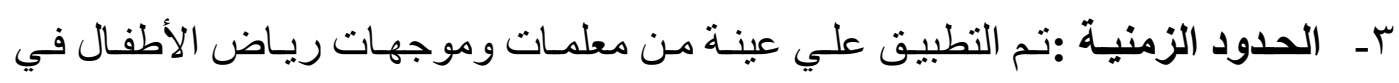

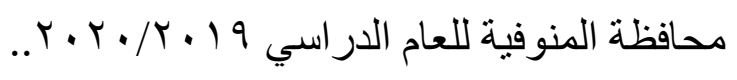


عـ الحدود الموضـوعية : اقتصـر البحث علي ثنلاثـة مجـالات لمعوقـات تـدريب معلمـات ريـاض الأطفال الغير متخصصـات أثتـاء الخدمـة كالتـالي ،(مجـال المعوقـات الإداريـة، مجال المعوقات الفنية، مجال المعوقات الشخصية) وكذلك بر امج تدريب معلمات ريـاض

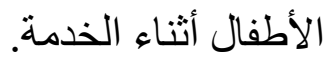

$$
\text { أدو ات البحث: }
$$

- استبانه موجهةة لمعلمات رياض الأطفال الغير متخصصات وموجهات ريـاض الأطفال تقييم البر امج التدريبية المقدمة إلي معلمات رياض الأطفال الغير متخصصات . مصطلحاث البحث: :

$$
\text { التدريب أثناء الخدمة : In-service Training }
$$

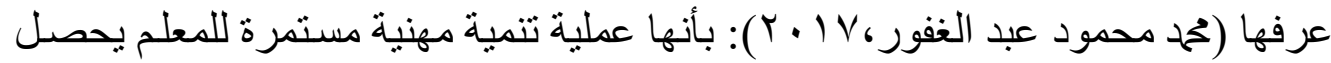
عليها بعد تخرجه من كليات إعداد المعلم، الهدف منها التطوير المستمر للمعلم ومو اكبـة الانفجار المعرفي و التكنولوجي، و الإطلاع علي كل مـا هو جديد في مجال التربيـة و التعليم بشكل عـام و التخصص بشكل خـاص، ويـأتي التدريب تلبيـة لاحتياجـات المعلمين بجميع المجالات، بهدف تحسين الأداء، مما بنعكس إيجابياً علي المتعلمين . معلمـات ربـاض الأطفـال غيـر المتخصصـات: Non-specialized Kindergarten

\section{Teacher}

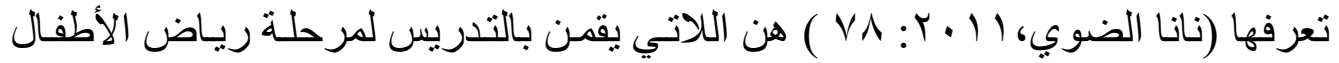
ويعملن بمؤ هل عالي ولكن ليس تخصص رياض الأطفال ويكونن من خريجات ( خدمة اجتماعية ـ تجارة - فنون جميلة...إلخ) ويتم تعيينهن بعد حضور هن مجمو عة من الدور ات التدريسية التي تؤ هلهن للعمل في الروضة. وتعرف أيضاً المعلمة غير المتخصصـة هي المعلمة التي لا تمتلك المعرفة و المهار ات المتعلمة لمهنة تربية الطفل و التي ستمكنهن من أن يصبحو ا معلمين مؤهلين لتعامل في مرحلة ريـاض الأطفال و الذي يتم من خـلال مجموعـة مـن الأدوار التي تمارسـها في ريـاض الأطفال (التخطيط و التنفيذ و التقويم للنشاط التربوي). 
معوقات تدريب المعلمات أثناء الخدمة:

\section{Obstacles to in Service training of female teachers}

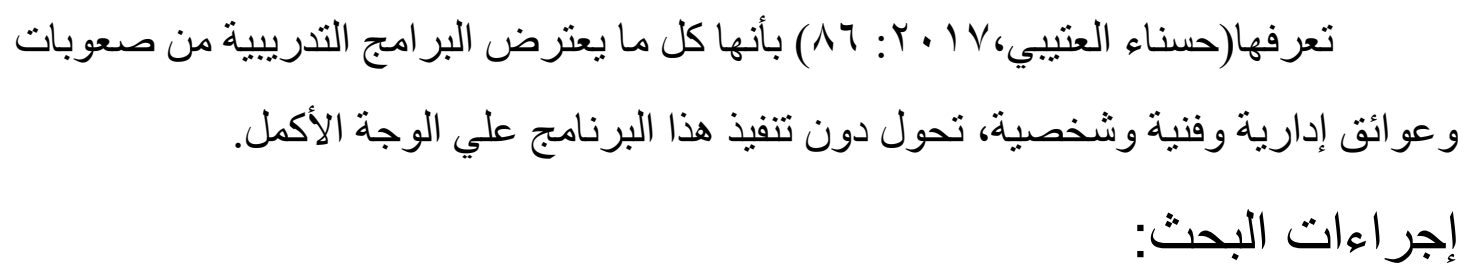

سار البحث الحالي طبقاً للإجر اءات التالية:

1 - الإطلاع علي الأطر النظرية والدراسات السابقة المرتبطة بأهية تدريب معلمات رياض

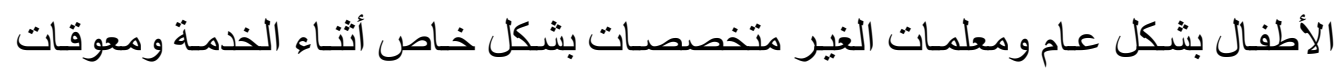

تدريب المعلمات أثناء الخدمة .

r- إعداد الاإستبانة الخاصة الموجهة لمعلمات رياض الأطفال الغير متخصصات وموجهات

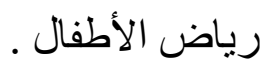

r- م- إجراء التجربة الإستطلاعية.

ـ - تطبيق الإستبانه علي العينة.

0ـ المعالجة الإحصائية للبيانات.

7- الإجابة علي تساؤ لات البحث.

V- الوصول للنتائج ومناقثتها وتقديم توصيات ومقترحات البحث في ضوء نتائج البحث.

$$
\text { الإطار النظري للبحث: }
$$

مفهوم التدريب أثناء الخدمة: In service Training concept

يعد تنريب المعلمين أثناء الخدمة أحد مرتكز ات تربيـة وتكوين المعلم لأن تربيـة المعلم

عملية ذات وجهين، يتمثل الوجه الأول في الإعداد قبل الخدمة، والثاني في التدريب أثناء الخدمة، أي أن الوجهين متكاملان، وعمليـة الإعداد قبـل الخدمـة بدايـة الطريق و التـدريب أثنـاء الخدمـة

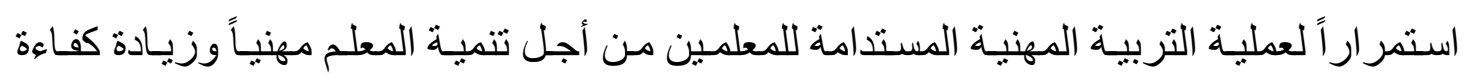
المؤسسـة التربويـة ومخرجاتها، و إذا مـا أحسن استغلال عمليـة التـدريب المعلمين أمكنـا تحقيق 
الكفاءة المثلي للنظام التعليمي ووضع نظرياته موضع التطبيق لتحقيق الأداء الأفضل وصو لاً إلي النمو و الرخاء للمجتمع. و عرفت (رانية جعفر محمد ، 10 ـ ؟ . . 1 ) التدريب أثناء الخدمة بأنها مجمو عة الأداءات التدريبية المنظمة المخطط لها بناء علي الأحتباجات التدريبية المتجدة، والتي تسهم في دعم النمو المهني لمعلمـات ريـاض الأطفـال الموجـودات بالخدمـة في جو انـب التـدريب الثنلاث الثقافـة، و المهنية، و التخصصية.

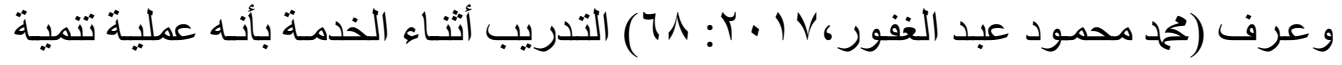
مهنية مستمرة للمعلم يحصل عليها بعد تخرجهه من كليات إعداد المعلم، الهدف منها التطوير المستمر للمعلم ومو اكبـة الانفجـار المعرفي والتكنولوجي، والإطلاع علي كل مـا هو جديد في مجـال التربيـة و التعليم بشكل عـام و التخصص بشكل خـاص، ويـاتي التدريب تلبيـة لاحتياجـات المعلمين بجميع المجالات، بهدف تحسين الأداء، مما ينعكس إيجابياً علي المتعلمين. وتعرف الباحثـة التـدريب أثنـاء الخدمـة بأنـه مجمو عـة مـن البر امج و الأنثطة التدريبيـة المخطط لها بناء علي احتياجات معلمات رياض الأطفال الغير متخصصات وفق أهداف و اضحة وبأساليب متطورة تثري اللقاءات التربوية مما بنعكس علي زيادة فاعليتهم التعليمية. أهداف تدريب المعلمات أثناء الخدمة: هنـاك العديـــ مـن الأهـداف التـي تجعـل مـن تـدريب المعلمـات أثتـاء الخدمـة أمـر اً هامـاً وضرورياً، وتتمثل هذه الأهداف فيما يلي: (Botha Morie,2011) - - م - مبر ات الفنية و المهنية و التقافية. - تجديد وتحديث معلومـات الغير مؤهلين وتنميتها، لملاحقة التقدم العليمي و التطور ات التي تحدث في مجال العلوم التربوية ،وفي مجال العلوم الأخري التي يقوم بتدريسها. ـ ـ تتميـة الاتجاهـات الإيجابيـة لـدي المعلمـات نحـو تقدير ها لقيمـه عملهـا، و أهميتهـه والأثـار الاجتماعيـة والأقتصـادية المتصلة بعملهـا والتعامـل معه،و إقامـة العلاقـات الإنسـانية و الوعي

$$
\text { بأهميتها في المجالات التربوية. }
$$


- ت تجديد الدو افع الذاتية للمعلمة المتدربة، حيث يسـاعد في تحسين أدائها ورفع كفاءتها العلميـة علي إتاحـة فرص الترقي التي تسر ها وترضـي طموحاتها، فتسعي إلي جعل عملها هادفاً ومنظماً وذا قيمة وفاعلية.

ـ ـيـادة قدرة المعلمـة علـي التقويم الـذاتي في ضـوء النتـائج التي تحصـل عليهـا مـن نتـائج التحصـيلية للأطفـال،أو مـن توجيهـات الموجـه الفنـي المثـرف عليهـا، أو مـن توجيهـات و إرشادات مدير المؤسسة التعليمية. ـ ضمان عامل الاستقر ار للمؤسسـات التعليميـة التي يتدرب معلماتها،حيث يوفر لهم التدريب أثنـاء الخدمـة عنصـر المرونـة في المو اقـف المتنوعـة، و القدرة علـي مواجهـة المشـكلات المختلفة،كما يزيد من قدرتها علي التكيف مع المو اقف الأخري. - زيادة قدرة المعلمة علي استخدام المو اد الجديدة، فعلي سبيل المثال عندما تظهر خامـات فنيـة جديـدة ويشـيع اسـتخدامها في مجـال فنـون الطفـل ،سـر عان مـا ينتقل إلـي مسـتوي التقني المدرسـي،و هنا تو اجـه المعلمـة بتحـد جديـد، فالمعلمـة في حاجـة إلـي التـدريب و الاسـتعداد لاستخدام كل الموارد المهارية و اليدوية في هذا المجال، حتي تستطيع مو اجهة أهم المتغيرات الجديدة. ـ مساعدة المعلمات الغير متخصصات التي أنخرطت في مهنة التعليم دون تأهيل سـابق و التي يعوز ها أن تلم بالجو انب المعرفية و المهارية و المهنية الكافية لتعامل مع الأطفال. - تعويض النقص و عدم الكفاءة المهارية، مما يكون قد حدث أثنـاء فترة الإعداد، أو مـا استجد بعد الالتحاق بالخدمة. - زيادة العائد من رأس المال البشري، وذلك عن طريق استثمار طاقات المعلمـات و الإمكانـات المتاحة وتنظيم العلاقات الإنسانية لتحقيق أقصي فائدة ممكنة. - إتاحـة فرص التجديــ و الإبتكـار للمعلمـات، حيث تخلق البـر امج التدريبيـة جو لتقبـل أفكـار المعلمـات الجديـدة وتشـجيعها، كمـا تتيح الفرصـة للمعلمـات لكي يختبروا جدوي أفكـار هم الإبتكارية ومردودها العلمي و إذا ثبت صلاحيتها يتم نشر ها بين المعلمات. 


\section{أهمية تدريب المعلمات أثناء الخدمة:}

تزداد أهمية التدريب أثنـاء الخدمة وتتعاظم علي نحو خـاص في مر احل الإصـلاحات و التحو لات الكبري التي يشهدها أي مجتمع من المجتمعات لما تفرضه هذه التحو لات علي النظم التعليمية من ضرورة إحداث تغير ات كيفية ونو عيه تتنـاول فلسفتها و أهدافها ومـا يرتبط بها من مفـاهيم و أفكار وممارسـات تعليميـة ـو والمعلمـة أحد الـدعائم الرئيسية التي يعتمد عليهـا النظـام التعليمي في تحقيق أهداف هذا التغيير وبلوغ غاياته التي ترمي في الدقام الأول إلي تمكين النظام التعليمي من ترسيخ مقومات ثقافته التربوية الجديدة التي تثتاسب ومقتضيات نمطه الحضـاري الجديد.

ومـن هنـا تبـرز أهميـة التـدريب أثنـاء الخدمـة للمعلمـات باعتبـاره أسلوباً مهمـاً لنمو هم الهنني، ولحصولهم علي مزيد من الخبرات الثقافية والإجتماعية و الأخلاقية وقد أكدت علي ذلك در اسة (Shippen,Sondra,2014)، وكل ما من شأنه رفع مستوي جودة أدائهم مما يؤدي إلي زيادة مستوي إنتاجاتهم التعليمية.

فـالنمو المهني للمعلمـة بشكل عـام ومعلمـة الغير متخصصـة بشكل خـاص هو عمليـة مستمرة وشاملة لجميع مقومات مهنة التعليم تؤدي إلي تحسين كفايات المعلمات المهنية وتجويد مسؤولياتها التربويـة، وتزودهـا بكل مـا هو جديد في مجال المعـارف و المهار ات و السلوكيات المهنية التي يتطلبها عملها التعليمي، بالإضافة إلي إثراء ما يتوفر لديها منها من أجل رفع مستوي الأداء المهني و الإداري، والتواصل الفعـال مـع الزملاء في الحقل التعليمي.(رفيق عيسى،قيد

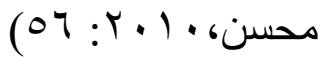
ولم يعد المجتمع البشري الحديث بحاجة إلي الدليل و البرهـان لإثبات العلاقة الفعلية بين أداء المعلمة و الإنتاجية الثاملة في المجتمع، وتكفي الإثـارة هنـا إلي دراسـة أجريت في النمسـا،

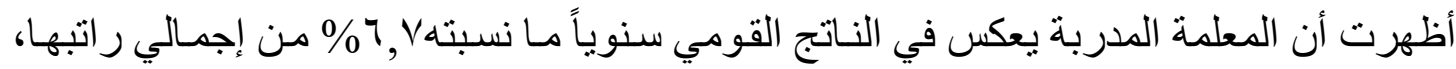
ويمكن إجمال أهمية تدريب المعلمات الغير متخصصات أثناء الخدمة من خلال مـا ذكره كل من

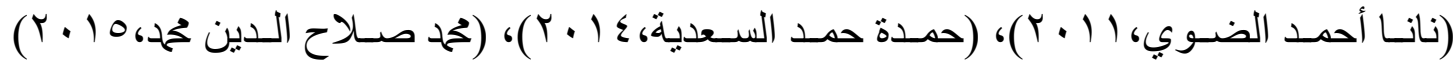
(Sharon.M.Carlson,2013) و (Tang,2010) في النقاط التالية: 
- رفع الكفاءة المهنية للمعلمة عن طريق صقل مهار اتها التدريسية ومسـاعدتها علي التأقلم

$$
\text { مع العمل المدرسي. }
$$

- إطلاع المعلمة علي الجديد و المستحدثات في مجال طرق التعليم وتقنياته، أو في محتوي

$$
\text { المنهج. }
$$

- تكسب المعلمة الغير متخصصـة ثقة بنفسها وقدرة علي العمل من دون الاعتمـاد علي

$$
\text { الأخرين ويدعم احتر امها لنفسها واحتر ام الأخرين لها. }
$$

- تكسب المعلمة الغير متخصصة معارف ومهار ات و اتجاهات ذات علاقة مباثـرة بالعمل

$$
\text { مما يطور أدوار ها المختلفة. }
$$

- معالجة القصور في إعدادها قبل الخدمة بالمعاهد و الكليات من خـلال تقديم تغذيـة راجعة

$$
\text { مناسبة لتنليل الصعوبات التي تواجهها في الميدان. }
$$

ـ الإستفادة من خبرات الأخرين من خلال العمل التعاوني في الورش و المناقثات ومختف

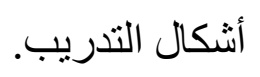

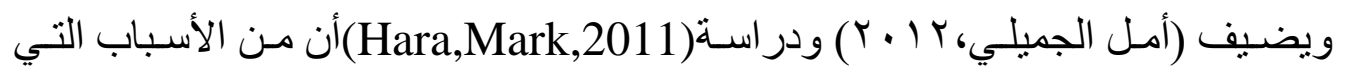

تجعل بر امج التدريب أثناء الخدمة مهمة أنها:

$$
\text { - تأهيلية: وذللك لتأهيل المعلمات غي المؤهلين تربوياً. }
$$

- تجديدية: وذلك لتجديد معلومات ومهار ات العاملين في المنظمـة أو المؤسسـة التعليميـة، وذلك لكون المتدرب بحاجة إلي المعرفة بإستمر ار، وإلي الإطلاع علي كل ما هو جديد

$$
\text { ومفيد في مجال عملها. }
$$

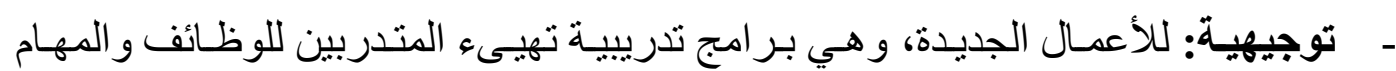

$$
\text { الجديدة التي توكل إليهح. }
$$

- مبائية: للعاملين الجدد، وهي برامج تهيىء المتدربين لمعرفة المجالات التعليمية التي

$$
\text { يتعاملون معها. }
$$

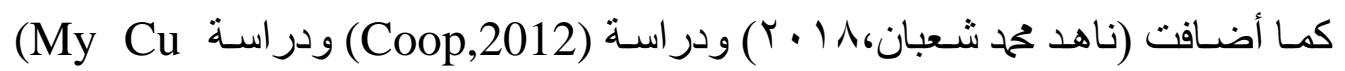
جملة من الوظائف تجعل من التدريب أثناء الخدمة عملية مهمة وهي: Sheri,2019) 
- وظيفة التعويض: عن طريق سد الثغر ات في مؤهلات المتدربين وتعويض النقص فيها

$$
\text { و الحاجة إلي استكمالها. }
$$

ـ وظيفة التكييف: وتتم عن طريق توجيه بر امج التدريب إلي الاحتياجات الجديدة و السـي

$$
\text { إلي تكييفهم مع المهمة. }
$$

ـ وظيفة إعادة التعليم: عن طريق تلبيـة المهام الجديدة المطلوبـة من المتدربين ومو اجهة

$$
\text { المستجدات العلمية و القدرة علي مو اجهة هذه المهام. }
$$

وظائف بر امج التدريب المعلمات الغير متخصصات أثناء الخدمة:

1 - مسايرة تطور التكنولوجيا ووسائل الأتصال:

تتعرض المعلمة في حياتها الوظيفيـة في عصدرنا الر اهن إلي متغير ات متسـار عة في

مجـال العلوم وتطبيقاتهـا التكنولوجيـة وفي مجـال وسـائل المعرفـة والاتصـالات، ومـن الوسـائل السمعية إلي الوسائل الصرية إلي التقنيات السمعية البصرية إلي الحوسبة و المعلوماتيـة، وكلها تقنيات حديثة ومتغيرة باستمر ار، و المعلمة الغير متخصصة في حاجـة إلي التدريب عليها لينمي معارفها عن طريق طريقها، ولتفيد المعلمات بها في تزويدهم بكل جديد،وتوظفها أثناء الموقف التعليمي.(James,2013)

\section{r- معالجة نواحي القصور في فترة الإعداد:}

لم يتلقي كثير من المدربات في أثنـاء إعدادهم مـا يؤ هلهم لأداء وظـائفهم المبدانيـة أداء كلاملاً، فبعضهم يعجز عن العطاء العلمي المنتظر، ومن ثم ينبغي أن يتم تدريبهم علي مـا فاتهم في أثناء الإعداد، وذللك إنقاذاً للمعلمة من اليأس والإخفاق ومن الشـعور بـالنقص الذي يسبب لها سوء التكيف مع وظيفتها في الحياة.(جمال محه كامل،1 ( • ب: 0 (1) ) ب- تطور النظريات التربوية:

تظهر بين الحين والأخر تطور ات في النظريـة التربويـة وفي الفلسفات التربويـة التي تعتمدها الدولة أو المجتمع، فتتغير من أجل ذلك الأهداف التعليمية وطر ائق التدريس و التدريب، وقد صار من الضـروري أن يحـاط القائمون بـالتعليم علماً بكل جديد، وبتغيير أدوار هم في كل 
فلسفة تربوية جديدة و لابد من إعادة تدريبهم للتكيف مع هذه الأدو ار حتي يقوموا بوظائفهم خير

$$
\begin{aligned}
& \text { قيام.(هالة حجاجي عبد الرحمن ، V ا . Y: ع 0) } \\
& \text { عـ تمكين المتعلم من الأدوار المتجددة: }
\end{aligned}
$$

لم تعد المعلمة الكفء هي من تقوم بنقل أكبر قدر من المعارف لأذهان الأطفال، ولم يعد للمعلمـة السـلطة المطلقة علي الصف، بـل أصبحت هـي التي تدير المو اقف التعليميـة وتهيـى الفرصة للتعلم وتوجه المتعلمين لحسن استغلال ما يتاح لهم من مصادر وموارد ليطورو ا قدر اتهم و إمكانـاتهم ويحققو ا تطلاعـاتهم وطموحساتهم، وليس أفضل من التدريب في أثنـاء الخدمة لتمكين المعلمة من هذه الأدوار المتغيرة.

0ـ - جودة أداء المعلمة:

يعمل التدريب أثناء الخدمة علي تحسين الأداء وتتمية كفاءة التربوين، بغية الوصول إلي درجة عالية من الإنتاجية وبأقل التكاليف و أقل الخسائر، ممـا يسهم في تحقيق التنميـة الإنسـانية الثناملة التي ينشدها المجتمع.(Seefeldt,2019:37) 7- - تغير العمل أو التخصص: وذلك في حـال انتقـال المعلمـة إلـي عمـل تربـوي أخـر كـالإدارة المدرسية و الإشـر اف

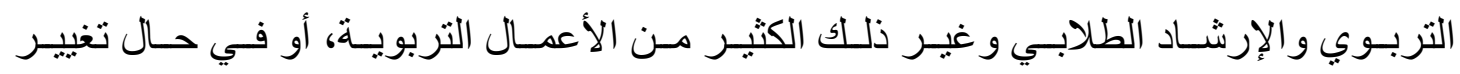
الاختصاص وتكليف المعلمة بتدريس مقرر أو أكثر ليس من تخصصسه الأكاديمي الدقيق، وهذا يستوجب تدريباً خاصاً لتمكين هذه المعلمة من النجاح في عملها الجديد. V- إتاحة الفرصة للنمو العلمي والرقي الوظيفي: ينبخي أن يكون باب الأمل مفتوحاً أم المعلمات إلي حياة أفضل و إلي الترقي الوظيفي من عملها الر اهن إلي عمل أرقي و التدرج من وظيفة إلي أخري أسمي منها و أفضل ولهذا أثره في ارتفاع معنو ياتها و إزدياد حيويتهم ونشاطهم وكل عمل جديد في مرحلة أو وظيفة جديدة يقضي لونـا معينـا مـن التـدريب الميـاني الملائم، يـزود فيـه المعلمـات بالجديـد مـن العلوم التخصصـية

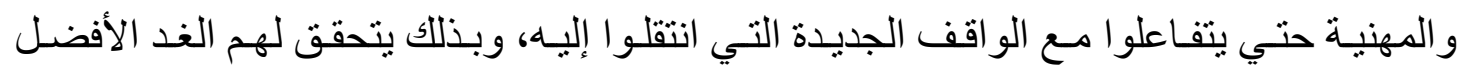

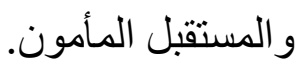




\section{أساليب التدريب أثناء الخدمة:}

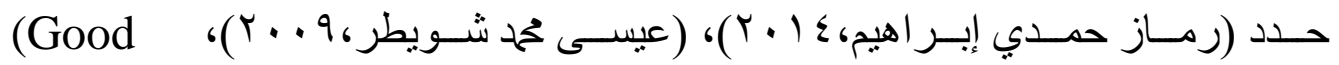

خمسة أساليب للتدريب أثناء الخدمة تمثلت في:

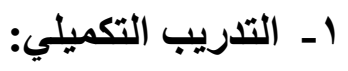

ويهذف لاستكمال بعض جوانب القصور في مرحلـة إعداد المعلمـة في مؤسسـات إعداد

المعلمات قبل الخدمة، وقد يكون هذا القصور في الجانب الأكاديمي أو في الجانب المسلكي.

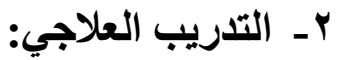

وذللك لمعالجة ضعف إحدي الكفايات التي يجب أن تتوفر لدي المعلمة.

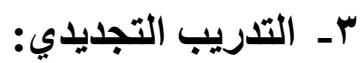

وذلــك لمســايرة المسـتجدات العلميـة والنظريـات التربويـة، والتطــور ات التكنولوجيـة

$$
\text { و التغير ات في أنماط الحياة. }
$$

ع - التدريب للأعمال والمهام الجديدة:

وذللك عندما ترشح المعلمة أثناء الخدمة لعمل تربوي أخر كالإدارة المدرسية أو الإشر اف التربوي وغير ها من الأعمال التربوية وذلك لتدريبها علي طبيعة العمل الجديد والمهام الجديدة المطلوبة منها.

$$
\text { 0ـ - مالتدريب الإنعاشي: }
$$

و هو تدريب الذي يقدم للمعلمة في أثناء الخدمة لإنعاثـها بمزيد من المعـارف و المهار ات إلي جانب تطوير الاتجاهات الإيجابية نحو العمل التربوي. الاتجاهات الحديثة في برامج تدريب المعلمات أثناء الخدمة: ينظر للتندريب أثناء الخدمة علي أنه بمثابة ضبط وتوجيه وحصر لطاقات النمو المهني الذاتيـة لدي المعلمـات، ودفعها نحـو إتقان مهار ات التعلم أو لاً و التعليم ثانيـاً وذلك لمبـدأ التعليم المستمر الذي أصبح ضرورة عصرية تفرضها عدة اعتبـار ات منهـا الانفجـار المعرفي وبخاصـة 
في مجال العلوم و التكنولوجيا، والذي يفرض علي المعلمة أن تظل علي اتصال دائم بالمستجدات في مجال تخصصها.

وتولي كافة النظم التعليمية الحديثة اهتمامـاً بإعداد المعلمات وتدرييهم وتأهيلهم لأهمية

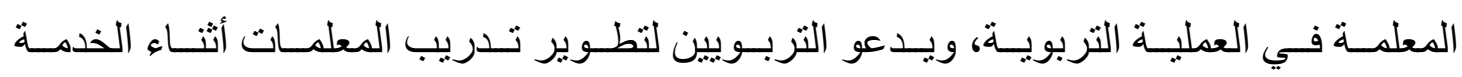
(Brown,2015,45) من مو اجهة أزمة التعليم في عالمنـا المعاصر ، كمـا أن تحديث العملية التعليمية من خـلال إعادة النظر جذرياً في نظام إعداد المعلمات وتدريبهر من خلال التركيز علي البحوث التربويـة وجعلها أكثر عمقاً وثزاء.

و عادة ما تعد بر امج تدريب المعلمات في أثناء الخدمة داخل المدارس بالدول الصناعية

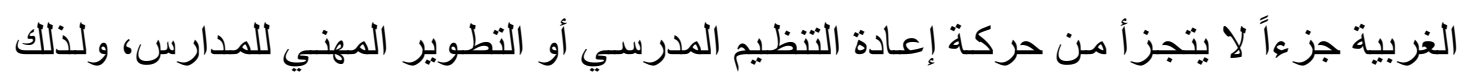
يرتبط التدريب المهني للمعلمات بالعمليات المدرسية مثل إدارة الذات، و التطوير المهني لأعضـاء هيئة التعليم، وتحسين المناهج كممارسين للمهنة لديهم القدرة علي تحسين أدائهم وتفاعلهم داخل الصف عن طريق اشتر اكهم في أبحاث نابعة من مشكلاتهم الحقيقية ففي اليابان، تم إصدار قانون

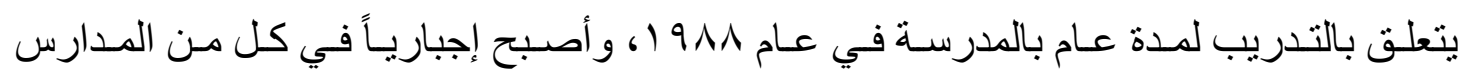
الابتدائية والثانوية و المدارس الخاصة في عام بو 9 1 ، ويستغرق برنامج التدريب يومين أسبو عياً

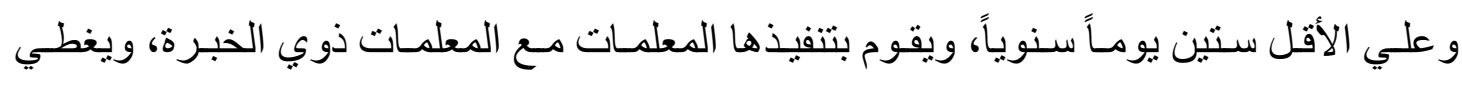
محتو اه كل ما تقوم بها المعلمة في الددرسـة، وتتضمن هذه البر امج اجتماعـات يتم فيها مناقثـة

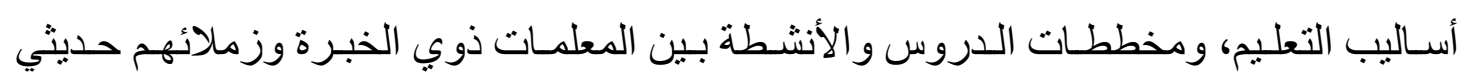
التعيين، ونعتقد أن هذا الاتجاه من أفضل الاتجاهات الحديثة في إعداد المعلمات وتدريبهر. مبادى تدريب المعلمات أثناء الخدمة:

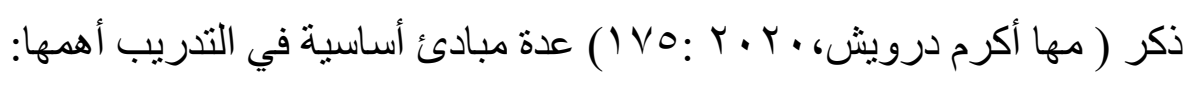
المبدأ الأول : اعتماد إطار أو نموذج نظري للتدريب: إن تدريب المعلمات الأكثر فعالية هو الذي يرتكز علي إطار أو نموذج نظري للتندريب له جذور في الحقائق التجريبية لاعتماده كإطار مرجعي لتوجيه النشاطات كالممارسـات التدريبية

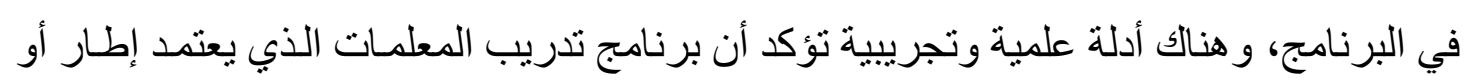


نموذجاً نظريـاً للتدريب يكون أكثر كفايـة وفعاليـة من البرنـامج الذي يفتقر لمثل هذا الإطسار أو

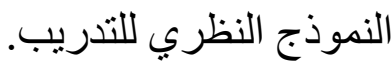

المبأ الثاني : وضوح وتحديد أهداف برنامج التدريب:

مـن أهـم العو امـل التـي تمكن المعلمـات المتـدربات مـن الاسـتفادة مـن برنـامج تـدريب

المعلمات أن تكون أهداف البرنـامج و اضحة ومحددة وأن تكون مصـاغة مـا أمكن بلغـة السـوك المتوقع ( صياغة إجر ائية) عند المتدربات.

المبدأ الثالث : تلبية الحاجات المهنية للمتدربات:

أن برنامج تدريب المعلمات القائم علي تلبية الحاجات المهنية للمتدربين يجعلهم يشعرون بأهمية هذا البرنامج بالنسبة للحياة العملية للمعلمات المتدربات ويمكنهم من الاضطلاع بـأدوار هم المهنية المقبلة في المدارس التي يعملون فيها بكفاية و اقتدار. المبأ الرابع : المرونة وتعدد الاختيارات في برنامج التدريب: أن برنامج تدريب المعلمات الأكثر فعالية هو الذي يتصف بالمرونـة من حيث متطلبـات القبول كالمتطلبـات الدر اسية ومتطلبـات التخر ج كمـا يتصف أيضـاً بتتوع الاختيـار ات المتاحـة المتاحة للمتدربين فيما بتعلق بإختيار المساقات الدر اسية كالنشـاطات التدريبيـة المتنوعـة، ويرتب علي هذا المبدأ أن مسؤولية تدريب المعلمات ليست مقصورة علي كليات إعداد المعلمـات و إنمـا يجب أن تتسع هذه المسؤولية بحيث تصبح مسؤولية مشتركة بين الدوائر الأكاديمية والكليات الجامعية.

المبدأ الخامس : توجيه برنامج تدريب المعلمات نحو الكفايات التعليمية:

من أبرز التحديات التربويـة في بر امج تدريب المعلمـات توجـه هذه البر امج نحو مبدأ الكفايات التعليمية الأساسية وحرص هذه البر امج علي إكساب المتدربات مجموعة من المهار ات التعليمية المطلوبة للمعلمة لتتمكن من الأضطلاع بدور ها التعليمي بفعالية، و إن هذا المبدأ يرتكز علي إكساب المتدربات مهار ات تعليمية سلوكية أو أدائية ضرورية للمعلمة لتسـاعدها علي القيام بمهام و أدوار محددة في الموقف التعليمي. 


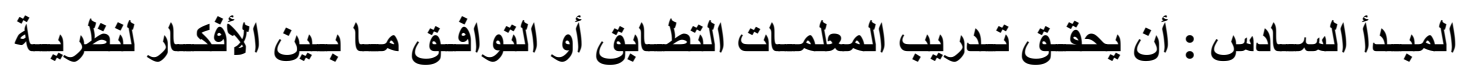

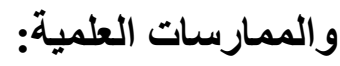

من أجل أن تحقق برنـامج تدريب المعلمـات أهدافها بفعاليـة ونجـا لابـد أن ير اعي في

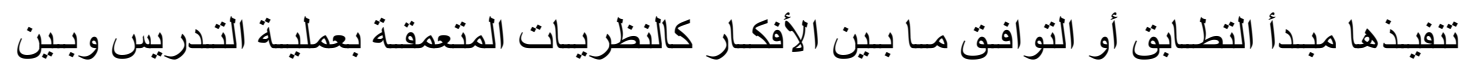
الممارسـات كالتطبيقات العملية في غرف النشـاط و إن معيـار الفعاليـة كالنجـاح لبر امج تدريب المعلمات يحدده مدي قدرة البرنامج علي ترجمة الأفكار النظرية إلي ممارسات أدائية أو إجر ائيسة يمكن ملاحظتها في سلوك المندربات.

المبأ السابع : استمرارية عملية تدريب المعلمات:

انسجاما مع الاتجاه العالمي المعاصر في تدريب المعلمات القائم علي النظر إلي تدريب

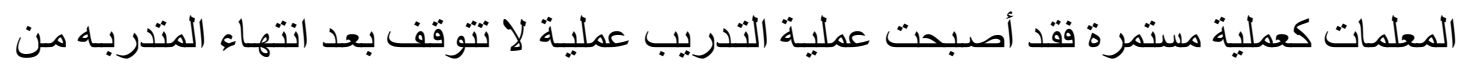
برنامج التدريب، وإن برنامج تدريب المعلمات الحديث ينظر إلي عملية التدريب علي أساس أنها عملية مستمرة تبدأ بالإعداد قبل الخدمة وتستمر طيلة الحياة المهنية للمعلمة.

المبأ الثامن : أن يمكن البرنامج المتدربات من تحقيق ذواتهم :

ومن الخصائص التي تتميز بها تدريب المعلمات الحديثة هو إتاحة الفرصـة للمتدربات

للمشاركة و التفاعل مع الموقف التعليمي- التعلمي وتثتجعه للمتدربات لكي يشـاركو ا في صناعة القرار ات المتعلقة ببرنـامجهم التـدريبي وأن ييسـر لهم البرنـامج التـدريبي فرص النــو الذاتي لامتلاك المهار ات كالكفايات المهنية الضرورية لمهنة التعليم، وأن البرنامج التدريبي الذي يساعد علي تحقيق ذوات المتدربات يكون لهن أكبر الأثر في شعور هم بالرضـا عن ذو اتهم الأمر الذي يترتب عليه الرضا عن المهنة في المستقبل كالثعور بالاكتفاء.

و اقع بر امج تدريب معلمات رياض الأطفال الغير متخصصات أثناء الخدمة في

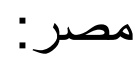

لقد بدأ الاهتمام بتدريب معلمات رياض الأطفال الغير متخصصات يتز ايد يوماً بعد يوم،

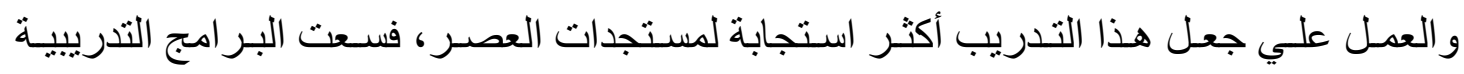
المطبقة إلي تمكين العاملين في رياض الأطفال وتطوير قدر اتهم ومهار اتهم، ليكونوا أكثر قدرة

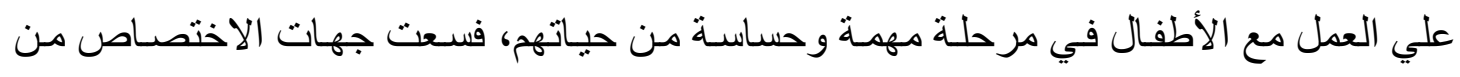


وز ار ات ومؤسسـات متخصصـه إلي إعداد وتقديم بـر امج تدريب وتأهيل متخصصـة لمعلمـات ريـاض الأطفـال الغيـر متخصصـات ،ضــن إطـار تربـوي هـادف ير اعـي خصـائص الطفولـة المبكرة، ومتطلباتها، و احتياجاتها الأساسية .

و علي الرغم مـن الأهميـة التي توليهـا وزارة التربيـة و التعليم لقضـية تـدريب معلمـات رياض الأطفال ومعلمات الغير متخصصات بصفة خاصة وتتمينهم مهنياً من خلال العديد من البر امج إلا أن المتأمل لهذه البر امج و الأنشطة يكتشف بها العديد من السلبيات و عدم تعدقها و أنها توضع في الغالب بعيداً عن الاحتياجات الحقيقية للمعلمات ،حيث تظهر بوضوح بعض جو انب القصور ويرجع ذلك إلي :

- عدم وضوح فلسفة التدريب و أهدافه وأولوياته فهو لا يساير السياسة التعليمية و لا يتو اكب مع الاحتياجات التدريبية مما أعاق تحقيق الأهداف المنشودة للتنمية لمهنية للمعلمات. - عدم تو افر كو ادر مدربة متفرغة بدرجة كافية تضطلع بتنفيذ البر امج التدريبيـة ممـا يتيح عنه عدم إحداث التغير ات المطلوبة في مهار ات المعلمات. - تو اضع الإمكانيات جعلت البر امج قصيرة المدي لا تحقق الغرض منها. - ضعف العلاقة بين مؤسسات الإعداد و التدريب وكليات التربية. - - ت شكلية تقويم البر امج و افتقار ها إلي المتابعة بعد الدور ات.

- عدم تو افر قاعدة بيانات دقيقة توضح لبر امج التدريبية وتنوعها. - نظـام التـدريب مـن خـلال الفيديو كونفر انس، يفتقد إلـي وجـود بـر امج عمليـة وتطبيقيـه وورش عمل ولقاءات مباشرة مكملة له.

- ضنعف نظام البعثات الخارجية لصغر مدة التدريب ونو عيتها. - - التدريب غير شامل ويركز علي الجانب التقني ويهمل الجانب الإنساني والأخلاقي. - بر امج التدريب الموجودة قديمة لا تصلح لإعداد معلمات المستقبل. أشكال التدريب أثناء الخدمة للمعلمات في مصر :

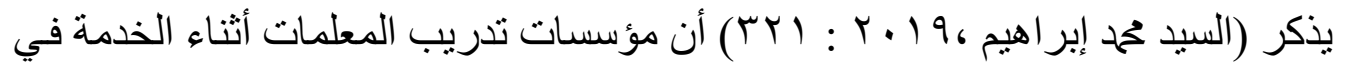
مصر تتعدد تبعا لتعدد أساليب التدريب حيث يقدم عدة أساليب من التدريب منها: 


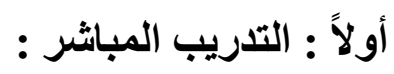

وفي هذا النوع من التدريب يتم اللقاء المباثر بين المتدربات من المعلمات و الدربين من

$$
\text { الكو ادر المتخصصة في المجالات المختلفة ويتم علي مستويين: }
$$

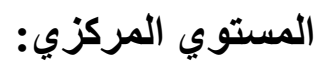

ويختص بـالبر امج الرسمية التي تقوم الإدارة العامـة للتدريب بوزارة التربية و التعليم

بوضع خططها علي مختلف مستوياتها.

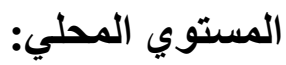

يوجد بكل مديريـة من مديريات التربيـة و التعليم بالمحافظـات إدارة تدريب تقوم بتنفيذ

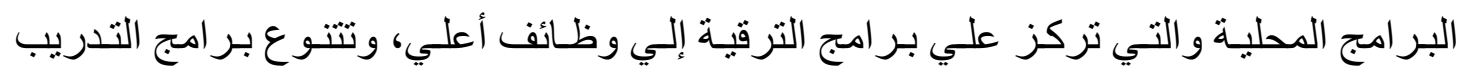
المقدمة للمعلمات إلي ثلاثة برامج و هي:

ا - برنـامج المعينين الجدد: ومدتـه خمسـة أيسام بو اقع أربع سـاعات يو ميـاً ويقدم هذا البرنـامج للمعينين حديثاً في العام الأخير.

r - برنامج تتمية مهار ات المعلمات الأو ائلِ: ومدته خمسة أيام بو اقع أربع سـاعات يومياً ويقدم للمعلمة الأولي.

r- برنامج المطور في كتب اللغنة الإنجليزية:مدة هذا البرنـامج ثلاثة أيسام بو اقع أربع سـاعات يو مياً ويقدم هذا البرنامج إلي معلمة و المعلمة الأولي في اللغة الإنجليزية.

ثانياً : التدريب عن بعد: - n

يقوم هذا التنريب علي استخدام التكنولوجيا و التوسع و الاعتماد علي التقنيات الحديثة في مجال التعليم وقد أنشئت وزارة التربية و التعليم مر اكز تطوير تكنولوجي بالمديريات التعليمية ويتم تدريب المعلمـات في هذه المر اكز باستخدام شبكة الفيديو كونفر انس وتستخدم الأليـاف الضـوئية والأقمـار الصـناعية للمنـاطق النائية، هذا بالإضـافة إلـي القاعـة الرئيسـة بـيوان عـام

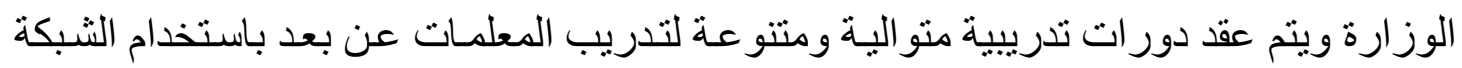
العنكبوتية في التدريب علي المناهج المختلفة والجديد فيها، ويعتبر التدريب عن بعد فرصـة لدعم الحوار العلمي وتبادل الأراء بين أكبر عدد من المعلمات في وقت واحد. 
ثالثاً : التدريب عن طريق البعثات الخارجية :

قامت الوز ارة لأول مـرة بوضـع خطـة لإيفـاد المعلمـات في التخصصـات المختلفة إلي الخـارج للتدريب علي الجديد في مجـال عمله في جامعـات المملكة المتحدة وفرنسـا والولايـات المتحدة الأمريكية.

ولكن في المجمل ما يز ال التدريب في أثتاء الخدمـة يعتمد بالدرجـة الأساسية علي نمط واحد، هو الدورات التدريبية، حيث يتطلب هذا النمط من التدريب توفير بني تحتبة تتو افر فيها المسـتلزمات المطلوبـة والقدر ات البشـرية المؤهلــة و المخصصــات الماليـة الكافيـة و التعليمـات التدريبيـة المرنـة التـي تتـيح لمسؤولي التـدريب الصـلاحيات اللازمـة لرسـم سياسـات التـدريب وخططه وتتفيذها بكفاءة، لكن الواقع الحـالي لا يفي بالمتطلبـات جميعها، حيث تتمثل المشكلات التي يو اجهها التدريب في هذا المجال في : قلق القاعات التدريبية وقدمها، و انعدام وسـائل الراحة للمتدربين، ونقص المستلزمات التدريبية علي نحو حاد، و عدم استيعابها للنشـاطات التدريبيـة، أمـا في يتعلق بالمدربين فلا يوجد دليل لتوصيف المدرب أو القائد التدريبي واختياره، كمـا أن أغلب القدر ات البشرية العاملة في مجال التدريب ينقصها الخبرة و الكفاءة والمؤهل التدريبي، فضلا عن انعدام الدافعية للعمل في مجال التدريب لافتقار هذا المجال إلي الحو افز و البيئة التدريبية الملائمة، مما يتطلب التفكير في اعتماد أنماط تدريبية أخري لا يتطلب تنفيذها بني تحتيـة متطورة وقدر ات بشـرية مؤهلـة كنمط المعلـم الزائر و الـدرس التـدريبي المشـترك و الـدرس التـدريبي النمـوذجي التلفزيوني وورش العمل التدربيية لرقعة جغر افية تضم مجمو عة من المدارس، أمـا بالنسبة إلي ألية تحديد الحاجات التدريبية فيجب فيها العمل علي إيجاد مصادر أخري لتحديدها غير المصدر التقليـدي و هـو تقـارير المشـرفين، كنتـائج البحـوث و الدر اســات الخاصــة بالتـدريب، ونتــائج الأمتحانات، واستيفاء المتدربين أنفسهم بالنسبة إلي حاجـاتهم التدربييـة أو الاتجاهـات المعاصرة في مجال التربية.

وبما أن بر امج تدريب المعلمات حالياً تتخذ شكلا جزئياً وغير متكامل وتفتقر إلي الموارد الضرورية لتوفير فرص التربية المستمرة للمعلمات، كما أن بعضها لا بعكس الحاجـات التدريبية الحقيقية للمعلمات، أصبح من الضروري تحديد الكفايات الأساسية للمعلمات وبناء أدوات للتحقق من نو افر ها وذلك لاستخدامها في بناء بر امج التدريب و التطوير المهني علي نحو عام وتحديد الاحتياج التدريبي علي نحو خاص. 
كما يفتقر التدريب إلي برامج لتقويم التدريب في كل مفاصله في أثناء التدريب وبعده، ومعرفة انتقال أثره إلي الموقف التعليمي، فلا توجد جهة مستقلة تأخذ علي عاتقها تقويم التدريب، إذ يعتمد هذا التقويم حالياً أسلوباً بسيطاً وبدائياً يتمنل في توزيع استمارة تقويميـة علي المتدربين في اليوم الأخير من الدورة، للتعرف علي مدي الفائدة من الدورات، لكن لا توجد متابعة لمعرفـة أثر التدريب، وبهذا الصدد يجب اعتماد أسلوب الرصد التدريبي داخل قاعة التدريب يقوم بـه أحد المتخصصين لتقويم النشاط التدريبي من جو انبه كلها، و إجر اءات البحوث و الدر اسات التي تثتاول التدريب من زو ايا مختلفة.

وفيمـا بتعلق بالمعلمـة المتدربـة نفسـها فتنعدم لديها بسبب عدم إدر اكها أهميـة التدريب ودور ها في تطوير ها المهني، لانعدام نظام يقرن التدريب بتقييم أداء المعلمـة وترقيتها الوظيفيـة، و من ثم يبقي متغير سـنوات الخدمـة التدريسية مـع بعض الدورات القصيرة المدي هو الثـرط الوحبد للترقي. وتؤكد بعض الدر اسات المسحية في الأدب التربوي علي أن هنالك قصور اً في البر امج و الدور ات التدريبيـة للمعلمـات، و أنها دور ات نظريـة لا تتضـمن جو انب عمليـة، وتنفذ في فترة زمنية قصيرة، وتتصف بعدم مرونتها، و عجز ها عن معالجة المشكلات التربويـة المستجدة، كمـا أن بعض المحاضرين ليسوا علي مستوي من الكفاءات المطلوبة (حسناء العتيبي، V • Y) وتؤكد در اسات أخري علي أن عملية الإعداد و التنميـة المهنيـة تفتقر إلي إطسار مفهومي و اضح، و إلي مساهمة المعلمات في تحديد موضو عات بر امج التدريب، سواء في التخطيط أو في التنفيذ والتقويم، كما أن الدورات التدريبية شكلية إلي حد كبير، و لا تحقق عائداً ملموسـاً في تنميـة الكفاءات المختلفة للمعلمات، كما أنها تفتقر إلي أسـاليب تقويم فعالة لمعرفة الأهداف التي تحقق منها، وتللك التي لم تحقق وإن بر امج الدورات التدريبية قليلـة الاهتمـام بتكنولوجيـا التعليم، نظراً لضعف الإمكانات المادية وبالتالي عدم ربط المحاضر ات النظرية بالتدريبات العملية، ممـا يؤدي إلـي عزوف المعلمـات عن حضـور الـور ات التدريبيـة بـل تكونـت لـيهم اتجاهـات سـلبية نحو التدريب، و عدم إحساسـهم بأهميتهـا في تتميـة مهار اتهـا الفنبـة، عـلاوة علي ذلك تشـير بعض الدر اسات إلـي أنـه لا يوجد في بر امج الإعداد والتنميـة المهنيـة مـا يفيد بـأن هذه البر امج تسـاعد المعلمات علي التفاعل و التكيف مع المتغير ات الثقافية و الاجتماعيـة و الاقتصـادية التي تحدث في المجتمع، أو دع تأثير هذه التغير ات علي نظام التعليم.(إبر اهيم زكي أحمد ، 9 ـ ـ ب: 77 ( ) 
وفي المقابل تتجه التطورات الحديثة في مجال التربية إلي منح المدارس المزيد من الدور و الريادة والاستقلالية للقيام بالدور التربوي في مجال تطوير عملية التعليم والتعلم لتطوير أداء المعلمات التعليمي من خلال تبني المزيد من المشـاريع التطويريـة و أنظمـة ديمقر اطية تسـاهم في لفي تحسين أداء المعلمات في عملية التعلم، وألا يقتصر دور الددرسـة علي تتفيذ التعليمات الإداريـة العليا فقط، وظهرت مفاهيم جديدة في التطوير التعليمي كالمدرسـة الذاتية في التعلم أو برنـامج المدرسة كمركز للتطوير. (لبني شعبان أحمد، · • Y ج ). إجر اعات عينة البحث الميدانية:

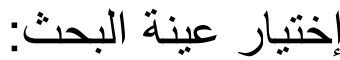
وقد تمت إختيـار بعد الإطـلاع علي مجتمع البحث الأصلي و الذي يتكون من جميع معلمات رياض الأطفال الغير متخصصـات و عددهم( • ) معلمـة و(70)موجهة رياض أطفال، وقد تم إختبار العينة بطريقة عشو ائية وتكونت عينة البحث من ( • ؛) مقسمة (Y0) معلمة،(10) موجهة بمرحلة رياض أطفال محافظة المنوفية

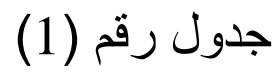

التوزيع التكر اري لعينة البحث وفقا لمتغير (عينة البحث) وفقاً لعينة البحث

\begin{tabular}{|c|c|c|c|}
\hline$\%$ & العدد & التوزيع & ᄅ \\
\hline 74.0 & ro & معلمة & \\
\hline$r V_{.0}$ & 10 & موجهة & $\bar{r}$ \\
\hline $1 \ldots$ & 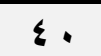 & & المجمو: \\
\hline
\end{tabular}

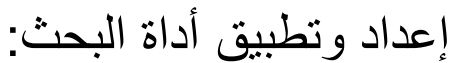

لتحقيق أهداف البحث استخدمت الباحثة استبانه موجهة لمعلمات رياض الأطفال الغير متخصصات وموجهات رياض الأطفال ،وظفت في جمع البيانات و المعلومات للإجابة عن أسئلة هذه الدر اسة و إنجاز ها، و علية قامت الباحثة بمر اجعة الأدبيات تقييم البرامج التدريبية الدقدمة إلي المعلمين بشكل عام ومعلمات رياض الأطفال بشكل خاص، وذلك للإستفادة في تحديد محاور

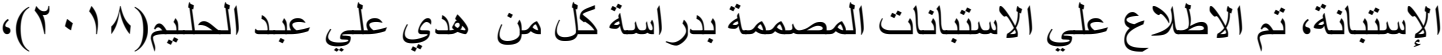

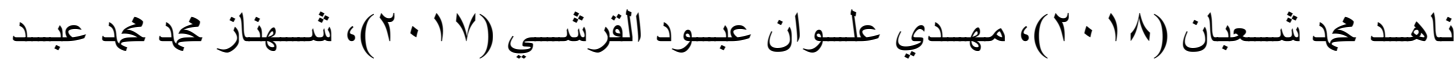

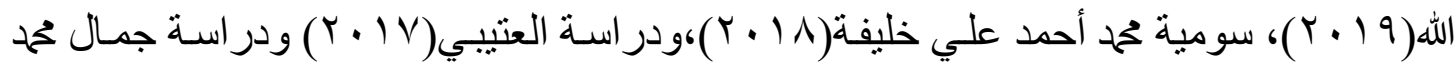




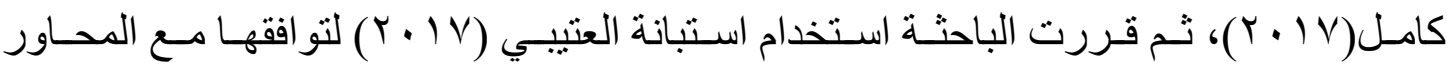
المستخدمة في الدر اسة الحالية وذللك بعد إجر اء بعض التعديلات لتتماثشي بشكل كامل مع أهداف

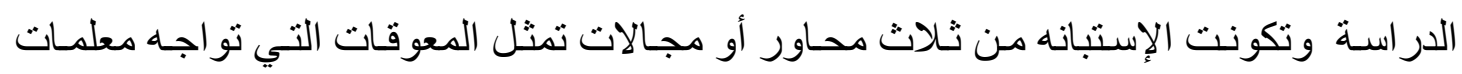
رياض الأطفال الغير متخصصات في التدريب أثناء الخدمة علي النحو التالي: - المحور الأول: يتعلق بالمعوقات الإداريـة التي تواجه المعلمـات الغير متخصصـات في التندريب أثناء الخدمة ويشمل(س (1) عبارة. - المحور الثناني: يتعلق بالمعوقـات الفنيـة التـي تو اجـه المعلمـات الغير منخصصـات في التدريب أثناء الخدمة ويشمل (r ا ) عبارة. - المحور الثالث: يتعلق بالمعوقات الثخصية التي تواجه المعلمات الغير متخصصـات في التدريب أثناء الخدمة ويشمل(r ( ) عبارة، ليكون المجموع الكلي للمفردات (ج) مفردة. حساب صدق وثبات الأستبانة: تتمتع الاستبانة بصورتها الحالية بدرجة مقبولة من الصدق و الثبات، حيث تم التأكيد من صدق بناء الاستبانة من خلال القيام بعدد من الإجر اءات وهي: - صدق المحكمين : من خلال عرضها علي عدد من المحكمين في مجال القياس و التقويم و أصول التربية والمناهج وطرق التنريس وقد أجمع المحكمون علي أن فقرات الاستبانة ملاءمة وتقيس ما وضعت لأجلة وترتبط بشكل قوي بالمجالات التي تقبسها. - - صدق الاتسـاق الاخلي لعبارات الاستبانة: تم حسابه من خلال تطبيق الإستبانه علي عينة استطلاعية قو امها ( · r معلمة وموجهة رياض أطفال ،وذلك بحسـاب معاملات ارتباط كل عباره من عبار ات الاستبانة و الدرجة الكلية للمحور الذي ينتسي إليههوذللك

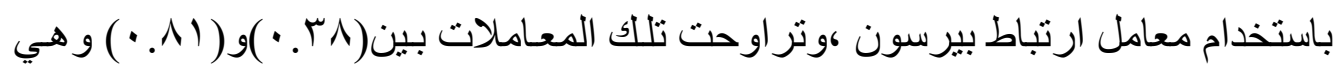
قيم مقبو لة ويمكن الاعتماد علي نتائجها. وللتأكيــد مـن ثبـات عبـار ات الاسـتبانة قامـت الباحثـة بتطبيقهـا علـي عينـة الدر اســة الاستطلاعية التي بلغ قو امها ( • r) معلمة وموجهة رياض الأطفال، ثم أعيد تطبيق الاستبانة مرة 
أخري بعد ثلاثتة أسـابيع علي نفس العينـة وحسـاب معامل الارتبـاط بين التطبيقين الذي بلغت قيمته(79. • ) و هو معامل ثبات مقبول يسمح بإستخدام الاستبانة علي العينة المختارة. الصورة النهائية للاستبانة :

تكونت الاستبانة من (9 (ب) مفردة بعبار ات واضحة ،يطلب فيها من المعلمة أو الموجهة تحديد المو افقة علي كل بند من بنود الاستبانة، حيث استخدم مقياس (ليكرت) الخماسي المتدرج، و المخصص لقياس الاتجاهـات والآراء حول بنود الاستبانة، والجدول رقم(؟) يوضـح توزيع الفئات وفق التدرج المستخدم في الاستبانة وذللك علي النحو التالي:

\begin{tabular}{|c|c|c|}
\hline مدي المتوسطات & الدرجة & الوصف \\
\hline 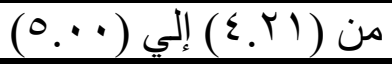 & 0 & أو افق بشدة \\
\hline 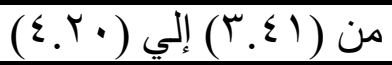 & $\varepsilon$ & أو افق \\
\hline 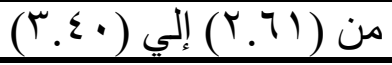 & $r$ & محايد \\
\hline 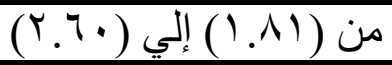 & $r$ & غير مو افق \\
\hline 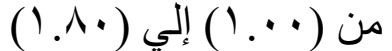 & 1 & غير مو افق بشدة \\
\hline
\end{tabular}

وتتكون الاستبانة مـن ثـلاث محساور أو مجـالات تمثنل المعوقـات التي تو اجه معلمـات رياض الأطفال الغير متخصصات في التدريب أثناء الخدمة علي النحو التالي: - المحور الأول: يتعلق بالمعوقات الإداريـة التي تواجه المعلمـات الغير متخصصـات في التدريب أثناء الخدمة ويشمل(r ا ) عبارة. - المحور الثاني: يتعلق بالمعوقـات الفنيـة التي تواجـه المعلمـات الغير متخصصـات في التدريب أثناء الخدمة ويشمل (س ( ) عبارة. - - المحور الثالث : يتعلق بالمعوقات الثخصية التي تو اجه المعلمات الغير متخصصات في التدريب أثناء الخدمة ويشمل(r ( ) عبارة، ليكون المجموع الكلي للمفردات (9 ب) مفردة.

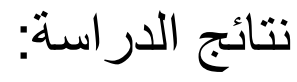

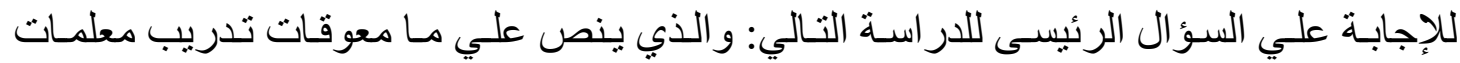

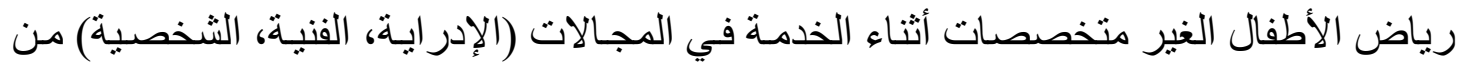

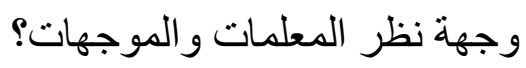




\begin{tabular}{|c|c|c|c|c|c|c|c|c|c|c|c|c|c|c|c|}
\hline \multirow{2}{*}{ الترنيب } & \multirow{2}{*}{ الألهبية } & \multirow{2}{*}{ الانحر افياري } & \multirow{2}{*}{ لالمتوسد } & \multicolumn{2}{|c|}{ أو افق بشدة } & \multicolumn{2}{|c|}{ أو افق } & \multicolumn{2}{|c|}{ محايد } & \multicolumn{2}{|c|}{ غير موافق } & \multicolumn{2}{|c|}{ غير موافق بشدة } & \multirow{2}{*}{ العبار ات } & \multirow{2}{*}{ r } \\
\hline & & & & $\%$ & العدد & $\%$ & |العدد & $\%$ & العدد & $\%$ & |العدد & $\%$ & العدد & & \\
\hline 1 & $91 .$. & .09 & $\varepsilon .00$ & - & - & - & - & 0 & $r$ & ro & $1 \varepsilon$ & 7. & Y $\varepsilon$ & 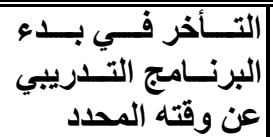 & 1 \\
\hline V & V7. 7. & .990 & $r . \wedge \mu$ & 0 & $r$ & $V .0$ & $r$ & Y.o & 1 & V. & $r \wedge$ & 10 & 7 & 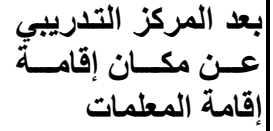 & $r$ \\
\hline ir & ro... & $\because V \varepsilon$ & 1.00 & $r v .0$ & 10 & 00 & $r Y$ & r.o & 1 & 0 & $r$ & - & - & 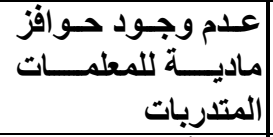 & $r$ \\
\hline$\Lambda$ & V $7 . \cdots$ & .99 & r.^. & 0 & r & $V .0$ & $r$ & 0 & r & $7 V .0$ & $r v$ & 10 & 7 & 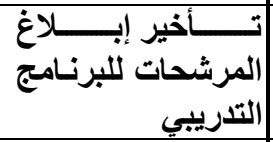 & $\varepsilon$ \\
\hline 7 & VV... &.$\wedge 9$ & r.Ao & 0 & r & 0 & r & Y.o & 1 & Vo & $r$. & $1 Y .0$ & 0 & 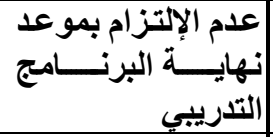 & 0 \\
\hline 0 & $\wedge r .$. & $.9 \mathrm{~V}$ & $\varepsilon .10$ & 0 & $r$ & Y.0 & 1 & Y.o & 1 & or.o & YI & rv.o & 10 & 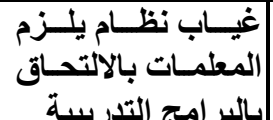 & 7 \\
\hline 11 & OY.E. & 1.1. & Y. TY & 1. & $\varepsilon$ & 0 . & $r \cdot$ & $1 \% .0$ & 0 & Yr.o & 9 & 0 & $r$ & 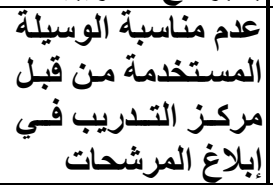 & v \\
\hline$r$ & $\wedge \wedge . \cdots$ &.$V V$ & $\varepsilon . \varepsilon$. & - & - & 0 & r & Y.o & 1 & $\varepsilon$ & 17 & 0 Y.o & Y I & 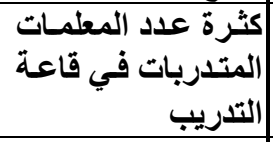 & $\wedge$ \\
\hline 9 & Vr... & $1.1 \%$ & r.70 & 0 & $r$ & 1. & $\varepsilon$ & ro & 1. & ro & $1 \varepsilon$ & ro & 1. & 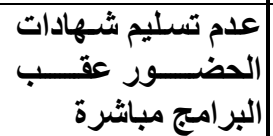 & 9 \\
\hline$r$ & AV. & $.9 V$ & $\varepsilon . \mu \wedge$ & Y.o & 1 & 0 & r & 0 & $r$ & $r v .0$ & 11 & 7. & $r \varepsilon$ & 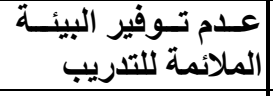 & $1 \cdot$ \\
\hline$\varepsilon$ & $\Lambda \varepsilon . \varepsilon$ & 1.89 & $\varepsilon . Y Y$ & $V_{.0}$ & $r$ & $V .0$ & $r$ & 0 & $r$ & 10 & 7 & 70 & Y & 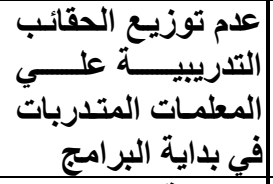 & 11 \\
\hline Ir & $0 \cdot \ldots$ &.$\wedge V$ & Y.o. & Y.o & 1 & 78.0 & $r V$ & $V .0$ & $r$ & Yr.o & 9 & - & - & في أمور جانبية وقت التـريب & $1 Y$ \\
\hline 1. & $7 V .7$. & $1 . \cdot v$ & ק. & 1. & $\varepsilon$ & 10 & 7 & Y.o & 1 & VY.O & rq & - & - & 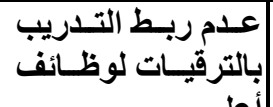 & $1 T$ \\
\hline - & $V Y . \& Y$ &.$r \varepsilon$ & Y. Y & & & & & "ر & ) & & & $b$ & & & \\
\hline
\end{tabular}

وللإجابة علي هذا السؤال، تم استخدام التكر ارات و المتوسطات و انحر افاتها، وترتيبها

كبناء علي إجابات العينة لمحاور البحث الثلاثة: 


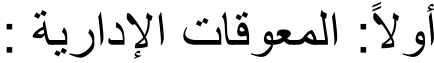

قامـت الباحثـة بحسـاب المؤشـر العـام المعبر عن كافـة فقـرات وبنـود إجمـالي محسور

(المعوقات الإدارية)، فقد تبين أن متوسط آر اء أفر اد العينة بلغ (rT.T؟) بانحر اف معياري يساوى

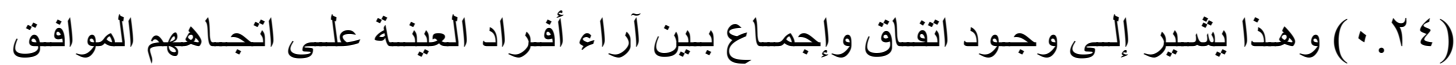

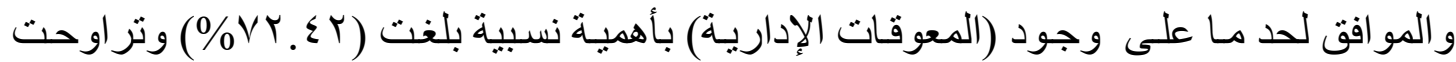

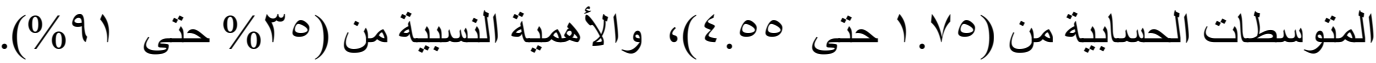
يتضـح ان أكثر العبـار ات موافقة في آراء المبحوثين على الترتيب: (التـأخر في بـدء البرنامج التدريبي عن وقته المحدد)، (كثرة عدد المعلمات المتدربات في قاعـة التدريب)، (عدم توفير البيئة الملائمة للتدريب)، (عدم توزيع الحقائب التدريبية علي المعلمات المندربات في بداية البرامج)، (غياب نظام يلزم المعلمات بالالتحاق بالبر امج التدريبية)، (عدم الإلتز ام بمو عد نهايـة البرنامج التدريبي)،( بعد المركز التدريبي عن مكان إقامة إقامة المعلمات)، وذلك بأهمية نسبية مقدار ها (\%)(\% كما يتضح: أيضاً أن أقل العبارات مو افقة في آراء المبحوثين على الترتيب: (عدم مناسبة الوسيلة المستخدمة من قبل مركز التدريب في إبلاغ المرشحات)، (هدر وقت التدريب في أمور جانبيـة)، (عـدم وجـود حـو افز ماديـة للمعلمـات المتـدربات)، وذلـك بأهميـة نسبية مقـدارها

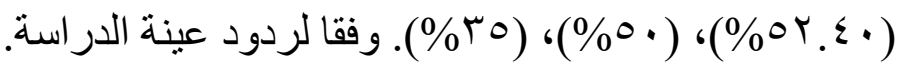


ثانباً: المعوقات القنبة:

جدول رقم (r) المقاييس الوصفية (المتوسط الحسابي والانحر اف المعياري

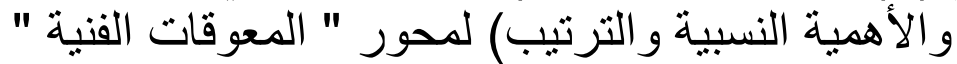

\begin{tabular}{|c|c|c|c|c|c|c|c|c|c|c|c|c|c|c|c|}
\hline \multirow{2}{*}{ الترثب } & \multirow{2}{*}{ النسبية\% } & \multirow{2}{*}{ |الانحر افياري } & \multirow{2}{*}{ الحستوس } & \multicolumn{2}{|c|}{ أو افق بشدة } & \multicolumn{2}{|c|}{ أو افق } & \multicolumn{2}{|c|}{ محايد } & \multicolumn{2}{|c|}{ مو غير } & \multicolumn{2}{|c|}{ غبير مو افق } & \multirow[t]{2}{*}{ العبار ات } & \multirow[t]{2}{*}{ r } \\
\hline & & & & $\%$ & العدد العد & $\%$ & | العدد | & $\%$ & العدد & $\%$ & العدد | العد & $\%$ & العدد & & \\
\hline 11 & $\Delta q_{.} \cdot$ & .911 & r.90 & 1. & $\varepsilon$ & 14.0 & 0 & OV.O & rr & 15.0 & 0 & $v_{.0}$ & $r$ & 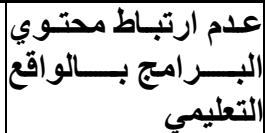 & 1 \\
\hline$\varepsilon$ & $V \leq . \leq$. & $1.1 \mathrm{~V}$ & r.VY & $v .0$ & $r$ & 1. & $\varepsilon$ & 1. & $\varepsilon$ & $\leqslant v_{.}{ }^{\circ}$ & 19 & ro & 1. & المستخذمة تقليدية ج & $r$ \\
\hline r & VY.\&. & $1 . r r$ & $r . \wedge r$ & 1. & $\varepsilon$ & 1. & $\varepsilon$ & $v_{.0}$ & $r$ & rY.o & $1 \%$ & $\varepsilon$ & 17 & 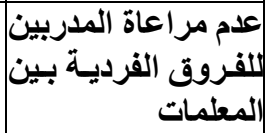 & $r$ \\
\hline$\bullet$ & $v \leqslant \ldots$ & 1.99 & r.v. & $v_{.0}^{\circ}$ & $r$ & $v_{.0}$ & $r$ & 1. & $\varepsilon$ & $0 v .0$ & $r r$ & IV.o & $v$ & بتساؤلات المعلبِ المدربات & $\varepsilon$ \\
\hline v & VI.\&. & $1 . Y_{1}$ & $r . \Delta V$ & 1. & $\varepsilon$ & $1 Y .0$ & 0 & 0 & $r$ & 00 & rr & $1 V .0$ & V & 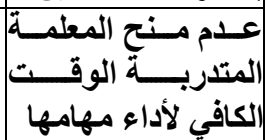 & 0 \\
\hline 7 & $v r . .$. & $1.1 \varepsilon$ & $r .70$ & 1. & $\varepsilon$ & $v .0$ & $r$ & 0 & r & 74.0 & ro & 10 & 9 & 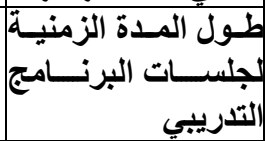 & 7 \\
\hline 7 & $v r . .$. & $1.1 \varepsilon$ & $r .70$ & 1. & $\varepsilon$ & $v .0$ & $r$ & 0 & $r$ & o. & ro & 10 & 9 & 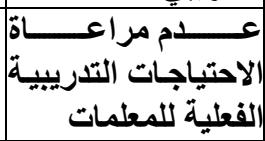 & $v$ \\
\hline$\wedge$ & $v 1 .$. & 1.14 & $r .00$ & 1. & $\varepsilon$ & 1. & $\varepsilon$ & 0 & r & 70 & rq & 1. & $\varepsilon$ & البرنامج توضيح عأهداف & $\wedge$ \\
\hline 9 & $v \cdot .7$. & $1.1 \mathrm{~V}$ & r.Or & 1. & $\varepsilon$ & $1 Y .0$ & 0 & 0 & $r$ & 7. & $r \leq$ & Ir.o & 0 & 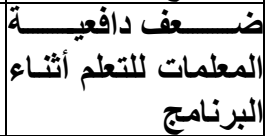 & 9 \\
\hline 0 & $V \varepsilon_{0}$. & 1.11 & r.v. & 1. & $\varepsilon$ & 0 & r & 0 & r & 10 & rq & 10 & 7 & عدام تصديبة بشيمِ الحقائب & 1. \\
\hline 1. & 71.7. & 1.50 & $r . \leqslant r$ & 1 1 .0 & 0 & 19.0 & 0 & 1. & $\varepsilon$ & 0. & $r \cdot$ & 10 & 7 & 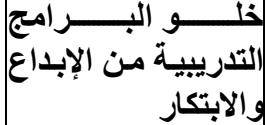 & 11 \\
\hline 1 & VV. . . & 1.99 & $r . \wedge \wedge$ & $v_{.0}$ & $r$ & 0 & r & 0 & r & $0 V .0$ & rr & ro & 1. & التـريبية للمدربين الكفــــاءة & ir \\
\hline$r$ & vo.. & 1.99 & r.v^ & $v_{.} 0$ & $r$ & $v .0$ & $r$ & 0 & $r$ & 7. & $r \leq$ & $r \cdot$ & $\wedge$ & 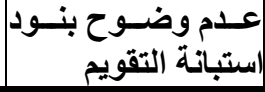 & ir \\
\hline - & VY.19 &.$r r$ & r. . & & & & & & & & & & & & \\
\hline
\end{tabular}

يتضح من الجدول السابق ما يلي:

- ق قامــت الدر اســة بحسـاب المؤشـر العـام المعبـر عـن كافـة فقر ات وبنـود إجمـالي محـور

(المعوقات الفنية)، فقد تبين أن متوسط آر اء أفر اد العينـة بلـغ ( • . ب؟) بـانحر اف معيـاري 
بساوى (r r • ) و هذا يشنير إلى وجود اتفاق و إجماع بين آراء أفر اد العينـة على اتجـاههم

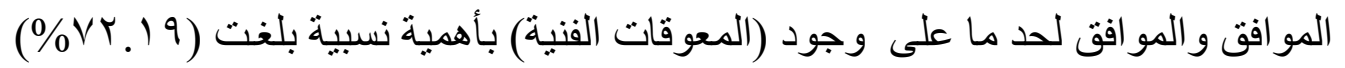

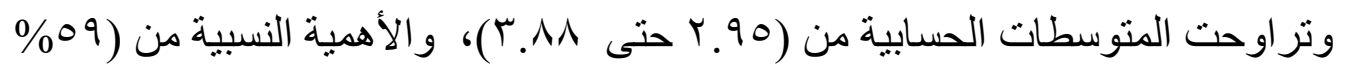

$$
\text { حتى . . . }
$$

- يتضح من الجدول ان أكثر العبار ات مو افقة في آراء المبحوثين على الترتيب: (انخفاض الكفاءة التدريبية للمدربين)، (عدم مر اعاة المدربين للفروق الفردية بين المعلمات)، (عدم وضـوح بنـود اسـتبانة التقويم)، (أسـاليب التـدريب المسـخدمة تقليديـة)، (عدم ترحيب المدربات بتسـاؤلات المعلمين، ( )، (طول المدة الزمنيـة لجلسـات البرنـامج التدريبي، عدم مر اعاة الاحتياجات التدريبية الفعلية للمعلمات)،( عدم منح المعلمـة المتدربـة الوقت

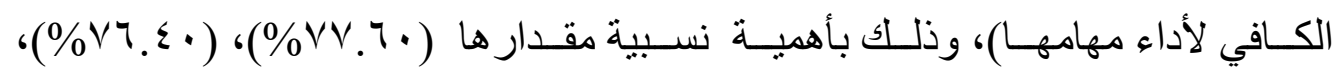

$$
\left..6(\% \vee)^{\prime} \varepsilon \cdot\right) \cdot(\% \vee r) \cdot(\% \vee \varepsilon) \cdot(\% \vee \varepsilon . \varepsilon \cdot) \cdot(\% \vee 0.7 \cdot)
$$

- كما يتضح من الجدول: أيضاً أن أقل العبار ات موافقة في آراء المبحوثين على الترتيب: (خلو البر امج التدرييية من الإبداع والابتكار)، (عدم ارتبـاط محتوي البر امج بـالواقع

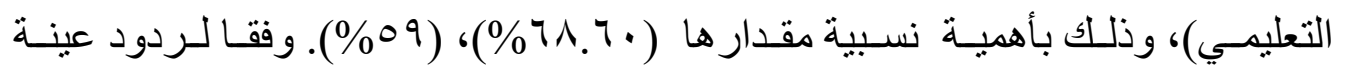
الدراسة. 
ثالثاً: المعوقات الثخصية:

جدول رقم (ع) المقاييسي الوصفية (المتوسط الحسابي والإنحر اف المعياري

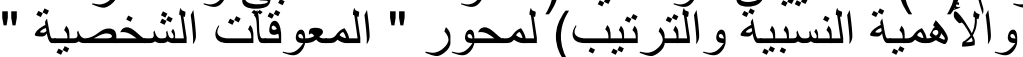

\begin{tabular}{|c|c|c|c|c|c|c|c|c|c|c|c|c|c|c|c|}
\hline \multirow{2}{*}{ الترتيب| } & \multirow{2}{*}{ النسبية\% } & \multirow{2}{*}{ |الانحر اف } & \multirow{2}{*}{ لالحست } & \multicolumn{2}{|c|}{ أوافق بشدة } & \multicolumn{2}{|c|}{ أو افق } & \multicolumn{2}{|c|}{ محايد } & \multicolumn{2}{|c|}{ غير موافق } & \multicolumn{2}{|c|}{ غيش مو افق } & \multirow[t]{2}{*}{ العبار ات } & \\
\hline & & & & $\%$ & العدد & $\%$ & | العدد & $\%$ & |العدد & $\%$ & |العدد & $\%$ & العدد & & \\
\hline$\varepsilon$ & $V \varepsilon .7$ & $\because 97$ & $r . v r$ & 0 & r & $v .0$ & $r$ & 1. & $\varepsilon$ & 10 & YT & $1 \% .0$ & 0 & 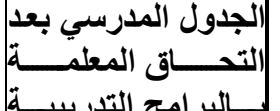 & 1 \\
\hline 1. & $\varepsilon V_{.} \cdots$ & .74 & r.ro & 0 & $r$ & 7. & $r \varepsilon$ & $r$ & ir & 0 & $r$ & - & - & 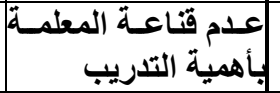 & r \\
\hline 1 & $v q_{.} \ldots$ & $1.1 \mathrm{~V}$ & $r .90$ & $v .0$ & $r$ & 0 & $r$ & 1. & $\varepsilon$ & $\varepsilon \cdot$ & 17 & $r v .0$ & 10 & 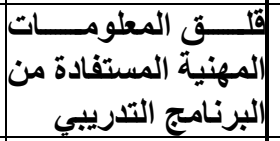 & $r$ \\
\hline$r$ & vo.s. & $\because \wedge q$ & r.vV & 0 & $r$ & 0 & $r$ & $v_{.0}$ & $r$ & $V Y .0$ & $r q$ & 1. & $\varepsilon$ & 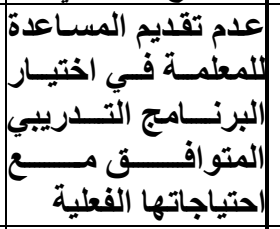 & $\varepsilon$ \\
\hline v & $V r_{.} .$. & .90 & T.7. & 0 & r & 0 & r & rV.o & 11 & 0. & $r \cdot$ & $1 \% .0$ & 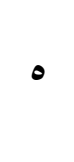 & 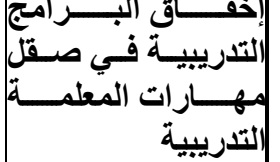 & 0 \\
\hline 7 & $v \varepsilon \ldots$ & 1.11 & r.v. & $v .0$ & $r$ & $v .0$ & $r$ & $1 Y .0$ & 0 & $0 r_{0}$ & YI & r. & $\wedge$ & 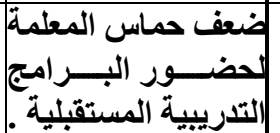 & 9 \\
\hline 11 & $\varepsilon r . \cdots$ & $\because \wedge 4$ & r.10 & IV.o & v & 7. & $r \varepsilon$ & 10 & 7 & 0 & $r$ & r. 0 & 1 & 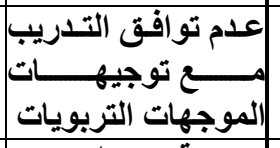 & $v$ \\
\hline$\varepsilon$ & $V \leq .7$ & $\because 9$. & $r . v r$ & r. 0 & 1 & vo & $r$ & $r$. & $\wedge$ & 00 & $Y Y$ & 10 & 7 & 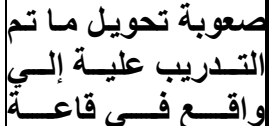 & $\wedge$ \\
\hline$r$ & vo... & $\because 9 r$ & r.vo & 0 & $r$ & Y.० & 1 & r. & $\wedge$ & $\bullet \vee .0$ & $r T$ & 10 & 7 & |للافتقار تقويم المدربات & 9 \\
\hline$\wedge$ & $v \cdot .7$. & $\because .09$ & r.or & - & - & 0 & r & $r V_{.0}$ & 10 & $0 V_{0} 0$ & $r r$ & - & - & 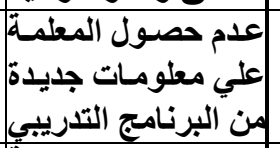 & 1. \\
\hline 9 & ov.s. & .99 & r.Av & 19.0 & 0 & $v .0$ & $r$ & 10 & rq & 1. & $\varepsilon$ & 0 & r & 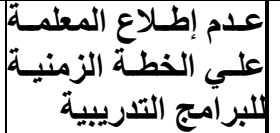 & 11 \\
\hline 0 & $V \varepsilon . \leqslant$ & 1.11 & $r . V r$ & $V .0$ & $r$ & V.o & $r$ & $v_{.0}$ & $r$ & 7. & $r \leq$ & IV.0 & V & 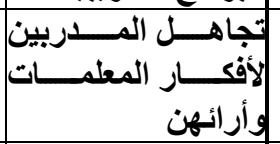 & Ir \\
\hline$\varepsilon$ & $V \leqslant .7$. & 1.99 & $r . v r$ & $v .0$ & $r$ & $v_{0} 0$ & $r$ & $v_{.0}$ & $r$ & 7. & $r \leqslant$ & 18.0 & V & 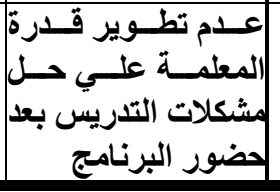 & 14 \\
\hline - & 71.01 & $\cdot r \varepsilon$ & r.\&Y & & & & & & & بـ & & & & & \\
\hline
\end{tabular}




\section{يتضح من الجدول السابق ما يلي:}

- ق قامت الدر اسـة بحسـاب المؤشـر العـام المعبر عـن كافـة فقر ات وبنـود إجمـالي محـور

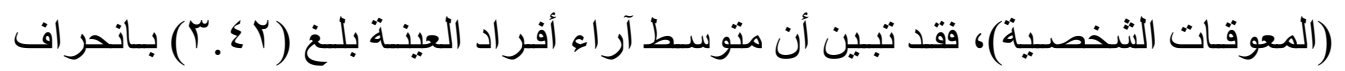

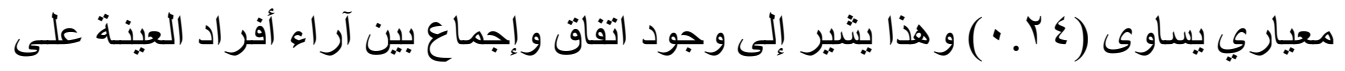

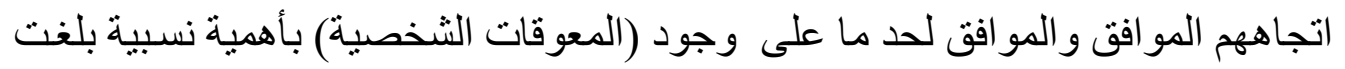

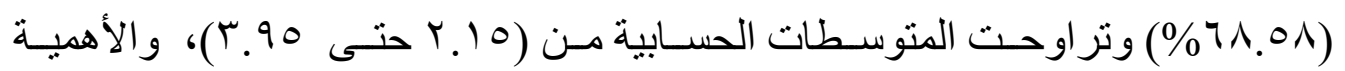

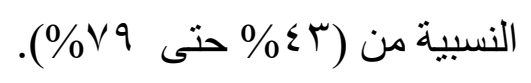

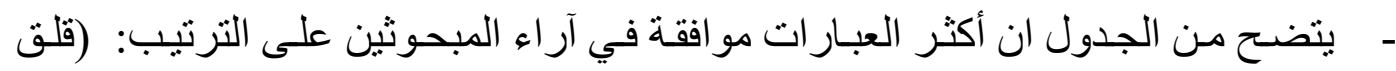

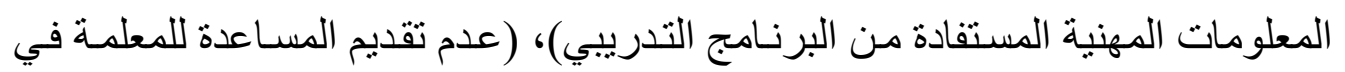

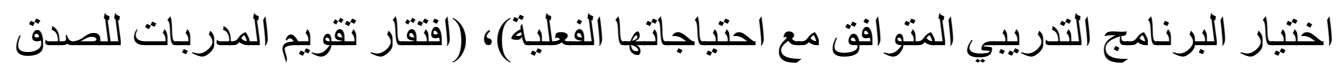

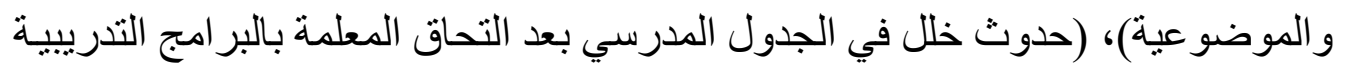

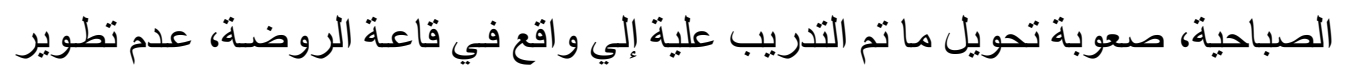

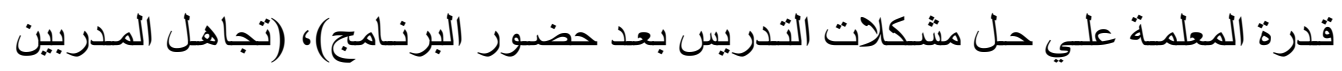

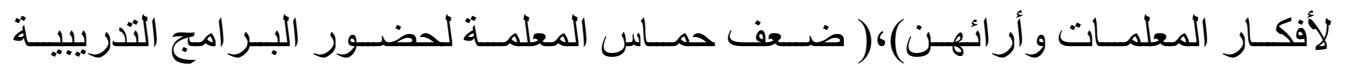

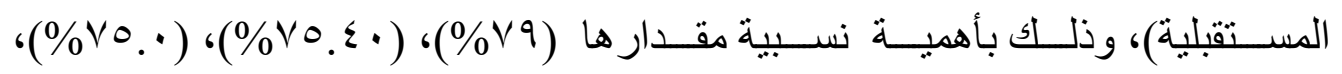

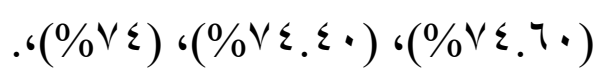

- كما يتضح من الجدول: أيضاً أن أقل العبار ات مو افقة في آراء المبحوثين على الترتيب:

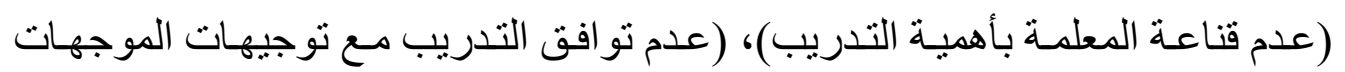

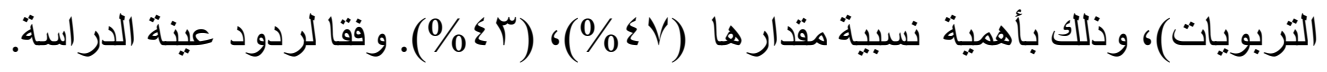

ملخص المقـييس الوصفية (المتوسط الحسـبي و الانحر اف المعيـاري و الأهميـة النسبية و الترتيب) لمحاور " معوقات تدريب معلمات رياض الاطفال الغير متخصصات اثناء الخدمة من ولنئ

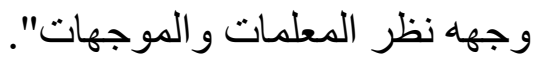


جدول رقم (0) المقاييس الوصفية (المتوسط الحسابي والانحر اف المعياري

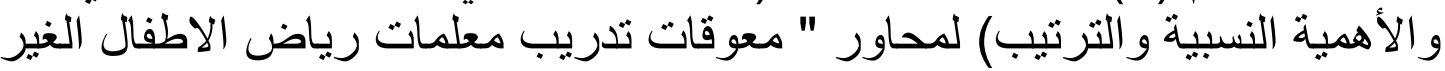

متخصصات اثناء الخدمة من وجها نظر التهو المعلمات و الموجهات

\begin{tabular}{|c|c|c|c|c|c|}
\hline الترتيب & الأهمية & الانحر افياري & الحسابي & المحاور & r \\
\hline 1 & VY.\&Y & $. . Y \leqslant$ & r.7r & |المعوقات الإدارية & 1 \\
\hline$r$ & VY.19 &..$r Y$ & r.7. & | المعوقات الفنية & $r$ \\
\hline$r$ & 71.01 & 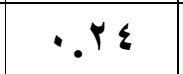 & $r . \leqslant Y$ & |المعوقات الثخصية & $r$ \\
\hline- & $v 1.97$ &. .10 & $r .00$ & العام لإجمالي المحاور " & متو \\
\hline
\end{tabular}

\section{يتضح من الجدول السابق ما يلي:}

- قامت الدراسـة بحسـاب المؤشـر العـام المعبر عن كافـة فقرات وبنـود إجمـالي محساور

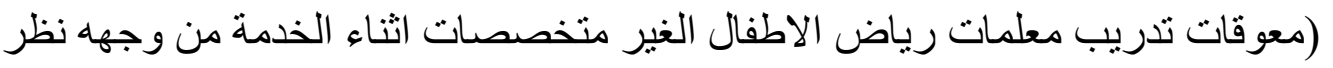

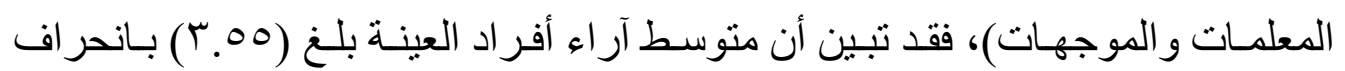

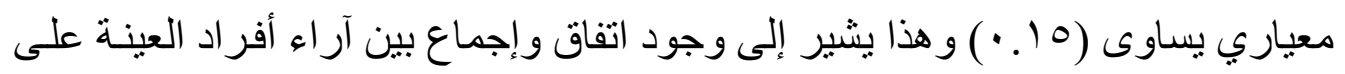

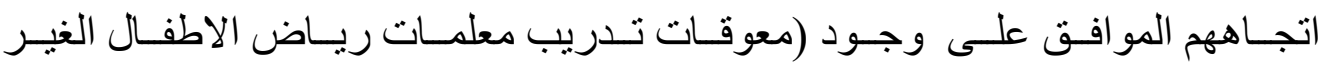

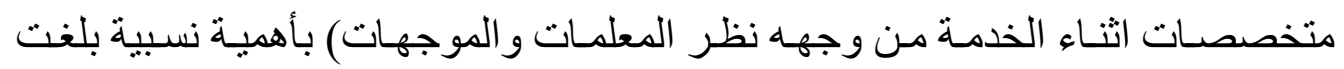

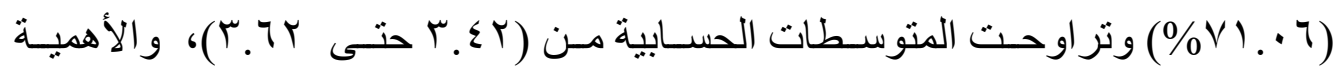

$$
\text { النسبية من (11.01. }
$$

- يتضح من الجدول ان أكثر المحاور اهمية في آراء المبحوثين على الترتيب: (المعوقات

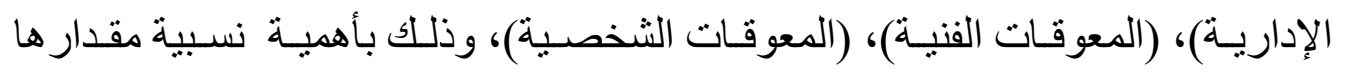

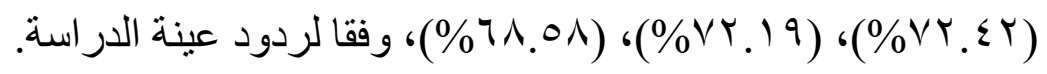
تعقيب علي نتائج البحث:

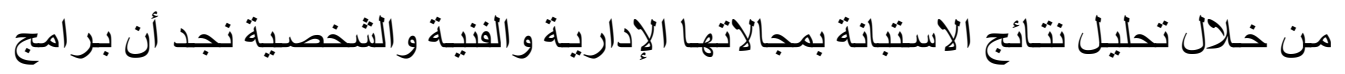

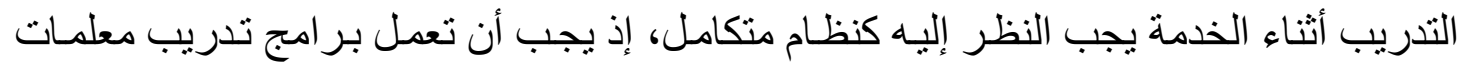

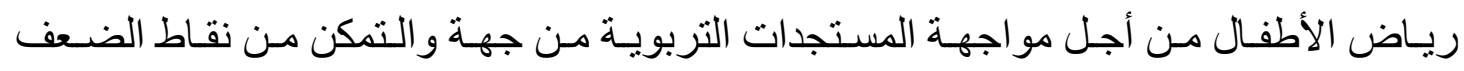

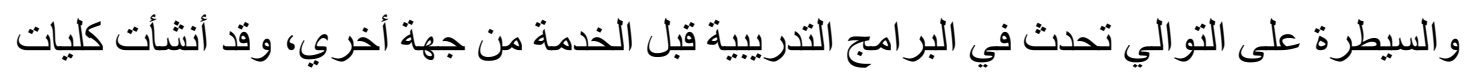

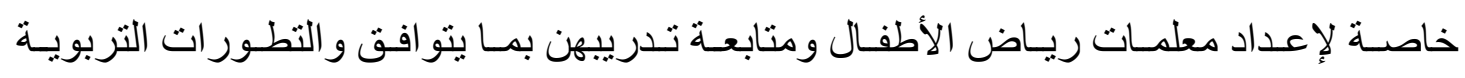

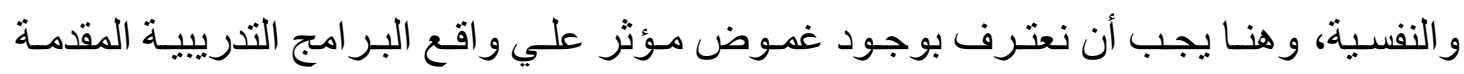

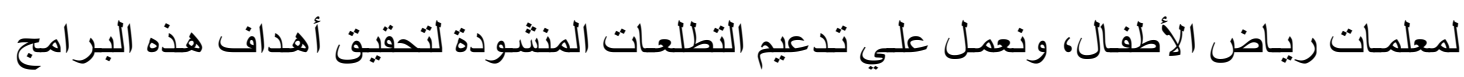


للنهوض بمستوي رياض الأطفال إلي مستويات متقدمة من التدريب الذي يجب أن ينطلق بدوره من احتياجات المعلمات أنفسهن، فمن الملاحظ عدم مشاركة المعلمات في التخطيط لتلك البر امج و هذا يعد من المعوقات الفنيـة التي تقف حائلاً دون تحقيق أهداف التدريب، ولذلك نلاحظ في مئني أغلب الأحيان عند الإعداد لهذه البرامج ظهور فجوة بين أهداف ومو اضيع وأساليب هذه البر امج، وبين احتياجات وطبيعة عمل معلمات رياض الأطفال ومدي تحقيقها لطموحاتهن التي كن يسعين إليها قبـل عقد مثل هذه الدورات التدريبيـة ،كمـا أن تدريب معلمـات ريـاض الأطفال يعـاني من الإعتماد علي الوسائل التقليدية في التدريب، بالر غم من المحاولات الجـادة للإبتعـاد عن الوسـائل التقليديـة، و الإسـتعانة بالتقتيـات الحديثة في ذلك، ولكن تتقصـها الإمكانـات الماديـة و البشـرية، وبالتالي فإن الوسائل المستخدمة في الغالب هي وسائل تقليدية تعتمد علي الجانب النظري بشكل

كما أن المقق في البر امج التدريبية المقدمة لمعلمات رياض الأطفال يجد أنها تركز علي الجانب

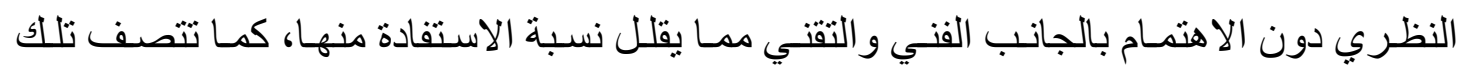
البر امج بالنمطية في التفكير وذلك لأن القائمين عليها غير مؤهلين بشكل كامل علميـاً وفنياً للقيام بالدور المنوط بهم بشكل مرضي، كما أن عملية التخطيط لتلك البرامج تتسم في أغلب الأحيان بالعثو ائية وذللك راجع إلي عدم تو افر قاعدة معلومـات عن سبر عمليـة التدريب، كما أن هناك

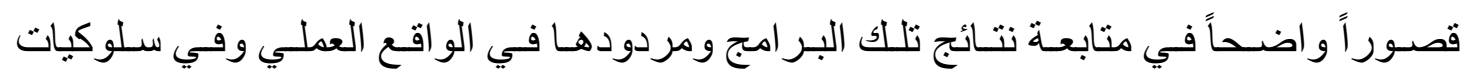
المعلمات فلا توجد معايير أو ألية واضحة يتم في ضونئها متابعة المعلمـات اللاتي حصلن علي تللك الدور ات.

\section{مقتر حات توصبات البحث:}

كثفت البحوث الميدانية لبر امج تدريب معلمـات ريـاض الأطفـال عن ظهور العديد من

أوجه القصور التي لازمتها وأدت فيها بعد إلي ضعف المردود التعليمي لها، ولذلك نستعرض في الته النقاط التالي مجموعة من التوصيات التي قد تقابل معوقات تطبيق البر امج التدريبيـة لمعلمـات رياض الأطفال أثناء الخدمة وقد روعي في هذه التوصيات أن تكون واقعة وقابلة للتنفيذ وتتفق مع النتائج التي أظهرتها الدر اسة الميدانية وذلك من أجل تطوير وتحسين البر امج التدريبيـة التي تقدم للمعلمات، وذلك علي النحو التالي:

1 ـ الإهتمـام بعمليـة النمـو المهنـي للمعلمـين مـن خـلال اسـتخدام أسـاليب جديـدة بنـاءً علـي

حاجاتهم المهنية و الإداريـة و التي تؤهلهم للعمل و الحصول علي تعلم ذي معني وفعـال ينعكس علي الأطفال، وذلك من خلال منح المعلمـات المزيد من الحرية و الديمقر اطية لتطبيق أفكار هم الذاتية و إظهار قدر اتهم الثخصية. 
r- تقديم الحوافز المادية و المعنوية للمعلمات بناءً علي نشاطهم وخبر اتهم و عملهم وقدر اتهم، حتي يشعرن بانتمـائهن للروضـة من خـلال تبني تقنيات جديدة في التعلم، وهذا يتطلب

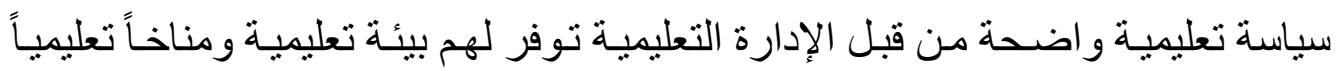
مناسباً لأدائهم الوظيفي. r- التعرف علي حاجات المعلمات المهنية في عملية التعليم وبناء وتقديم دور ات تدريبيـة في

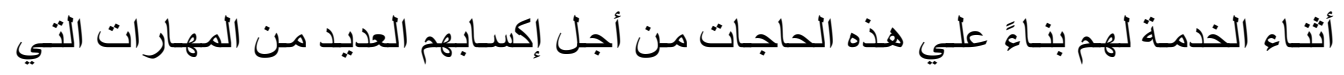
تساعدهم في التعامل مع مكونات الروضة المادية و المعنويـة بسـهولة، وتسـهم في تحقيق الأهداف المدرسية في أقل جهذ وتكلفة ووقت. عـ - بر امج التطوير ليست صيغة واحدة أو شكلاً أو نموذجاً واحداً من الاختيار ات، بـل هنـاك من الاختيار ات التي تأخذ صيغاً وأشكالاً ونماذج متعددة، لكن يبقي الأساس في الاختيار

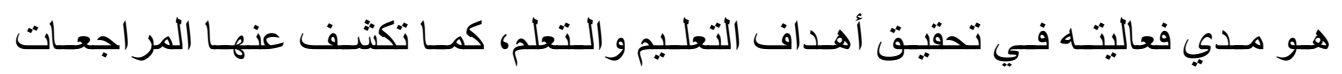
و التقويمات المستمرة. هـ تعطي بر امج التطوير المهني لمعلمات رياض الأطفال نتائج أكثر و أفضل إذا ما خضعت للتقو يم و المر اجعة المستمرين. جـ - يجب أن تكون بر امج التطوير المهني في و أثنـاء الخدمـة تتكامل مـع بر امج الإعداد قبـل الخدمة. V- ضــرورة مر اجعـة وزارة التربيـة و التعليم للدور ات التدريبيـة التي تخضـع لهـا معلمـات

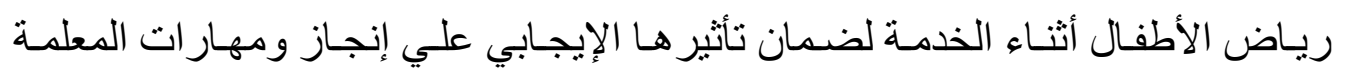
الخاصة في الموقف التعليمي. ^ــ مر اعاة التوقيت الذي ينفذ فيه الدورات التدريبية بحيث يكون مناسبا للمعلمات. 9ـ ضرورة مشاركة المعلمات و الموجهات التربويات عند التخطبط للبر امج التدريبية. • 1 ـ أن يتولي مسئولية التدريب مدربين أكفاء لهم دراية بمشكلات مرحلة ريـاض الأطفال

$$
\text { و المعلمة و احتياجاتها. }
$$

ا I - اعتبار كافة أنواع التدريب أساساً للترقية إلي وظيفة أعلي.

r ا ـ ضرورة تنوع أساليب التقويم بحيث تشمل علي جميع عناصر البرنامج التذريبي. با ـ تخصيص جزء كاف من البرامج التدريبية علي كيفية إعداد الوسـائل التعليميـة بهدف تيسير عملية التعلم. ع ا ـ ضرورة ربط أهداف البرنـامج التدريبي بمشكلات البيئة المحلية ومشكلات المجتمع القومي. 1 ـ أن يتولي تقديم الموضو عات التدريبية خبر اء مختصون في هذه المجالات. 
7 ا ـ ضرورة أن تتو افر قاعدة معلومات وبيانات و اضحة لدي القائمين علي عملية التدريب

حتي يتم التخطيط السليم لها.

V ا - ضرورة أن تكون هنالك متابعة مستمرة لنتائج البر امج التدريبيـة عن طريق الزيـار ات

الميدانية المستمرة من قبل الموجهات و التربوين للمعلمات المتدربات في الروضة. 1 ا ـ ضرورة أن تركز البر امج علي الجانب النظري و الفني أثناء التدريب.

9 ا ـ ينبغي الاطلاع علي الخبرات الدول المنقدمة و الاستفادة منها في ضوء مـا يتناسب مـع المجتمع المصري. • † - التأكيد علي استخدام الوسائل التكنولوجية الحديثة في التدريب. الدر اسات و البحوث المقتر حة:

1 - برنامج تدريبي لمشاركة المعلمات و الموجهات التربويات في التخطيط للبر امج التدريبية المقدمة لمعلمات رياض الأطفال الغير متخصصات. r- در اسة تقويمية للبر امج التدريبية لمعلمات رياض الأطفال الغير متخصصـات في ضوء خبر ات الدول المتقدمة.

ب- بنــاء بـر امج تدريبيـة بإسـتخدام الوسـائل التكنولوجيـة الحديثـة للتـدريب معلمـات ريـاض الأطفال الغير متخصصات.

عـ ــ وضـع بـر امج للتعرف علي حاجـات المعلمـات المهنيـة في عمليـة التعليم وبنـاء وتقديم دور ات تدريبية في أثناء الخدمة لهم بناءً علي هذه الحاجات . 


\section{مراجع الدراسة}

\section{أولاًَ المراجع العربية:}

1- إبراهيم زكي أحمد الصاوي(9 (1) ب): برنامج أنشطة حركية مقترح للحد من سلوك التنـر

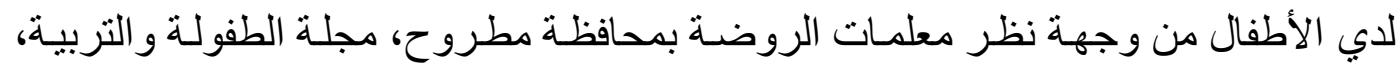

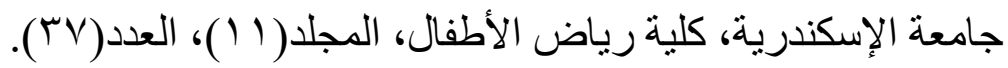
r- بلال خلف (11 + r): طرق إبداعية في التدريب، عمان، دار المسيرة.

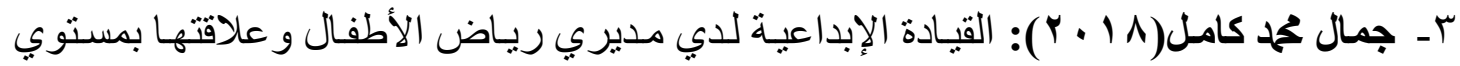
الأداء الوظيفي للمعلمات، مجلة كلية رياض الأطفال ،جامعة بورسعيد ،كلية رياض الأطفال،

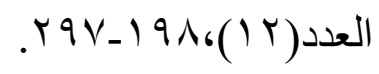

ع - حسناء العتيبي (Y V + Y): معوقات تدريب المعلمات أثناء الخدمة في مدارس مدينة الرياض

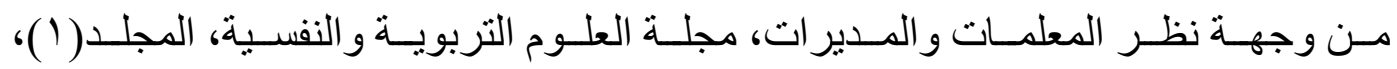

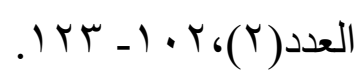

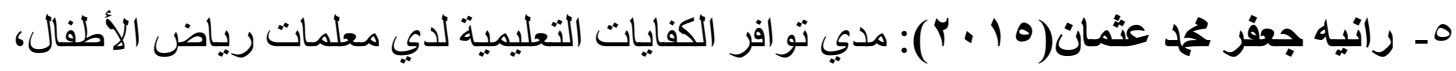
رسالة ماجستير ، معهد بحوث ودر اسات العالم الإسلامي، جامعة أم درمان الأسلامية.

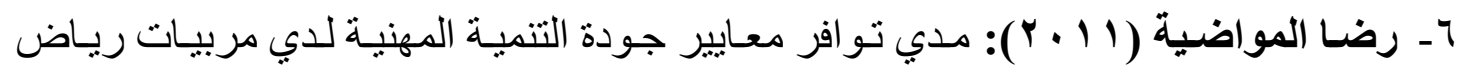
الأطفال بالمملكة الأردنية الهاثمية من وجهة نظر مدير ات الروضـة، مجلة رابطة التربيـة

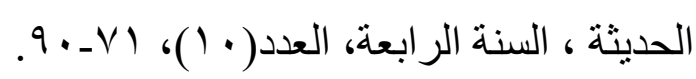

V- رفيق عيسي ،فقد ومحسن( • (Y)): تصور لتطوير الأداء التدريسي لمعلمي العلوم وفق

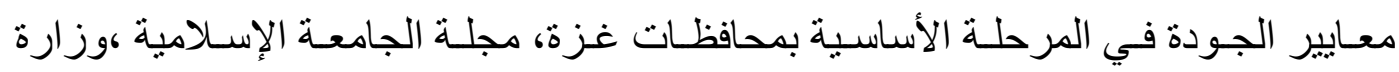

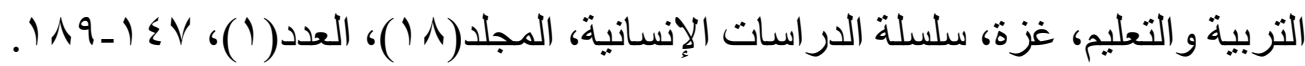

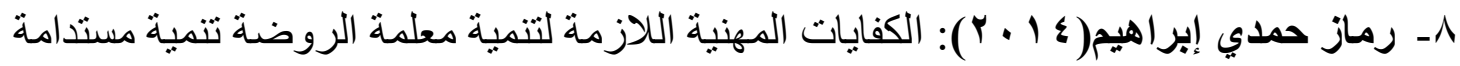

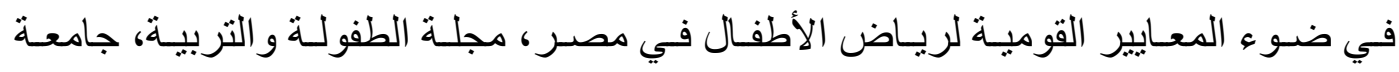

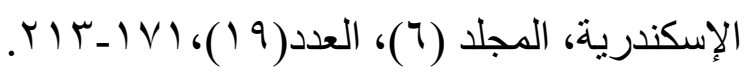

9 - ريم علي المغربي (7 ( + ץ): أثر التنمية المهنية ( التدريب ) أثناء الخدمة للمعلم علي دافعيته

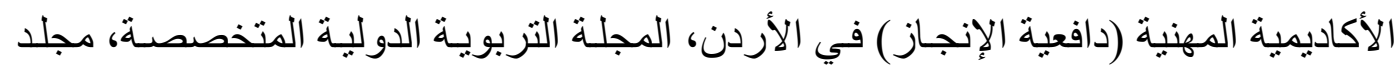




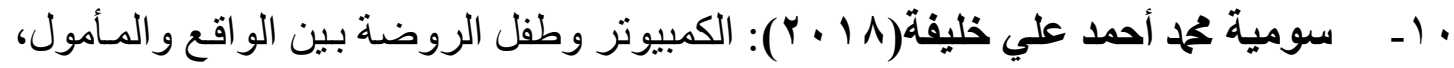

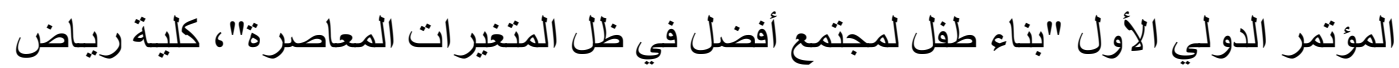

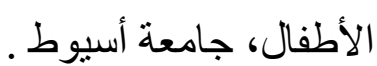

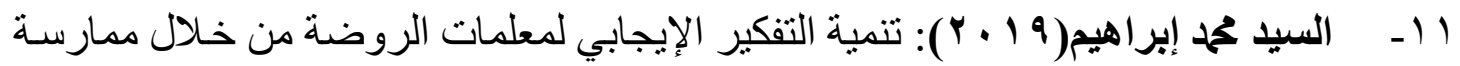

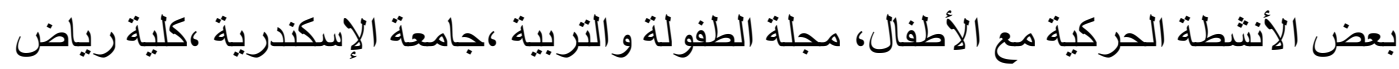
الأطفال، المجلد( (1)، العدد(1). (1).

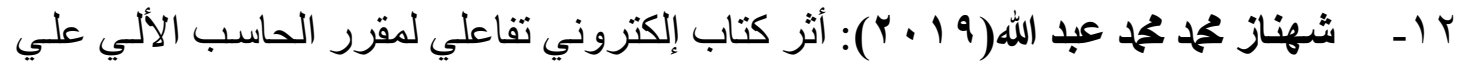

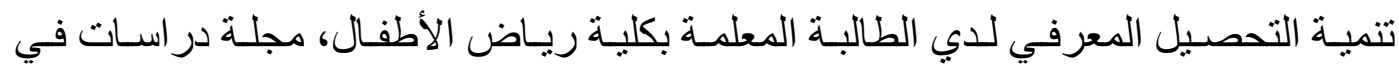

$$
\text { الطفولة والتربية، العدد العاثر، جامعة أسيوط. }
$$

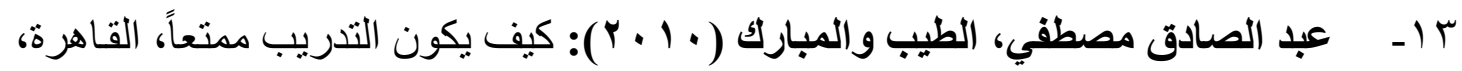

$$
\text { المكتب العربي للمعارف. - المبادي مصطي، }
$$

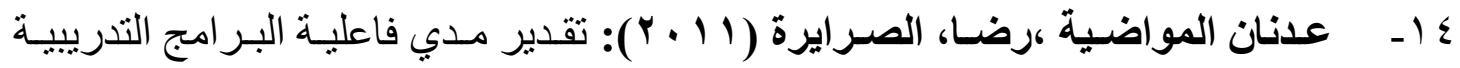
لمعلمات رياض الأطفال في مدارس محافظات إقليم الجنوب في المملكة الأردنية الهاثمية مـن وجهـة نظـر المعلمـات أنفسـهن، موتـهـ للبحـوث و والدراسـات، سلسـلة العلـوم الإنسـانية،

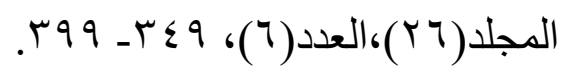

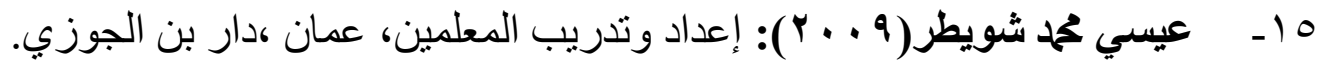
17

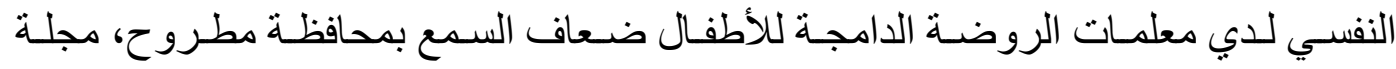
الطفولة و التربية، جامعة الإسكندرية ،كلية رياض الأطفال، المجلد( ( ) )، العدد( ( ).

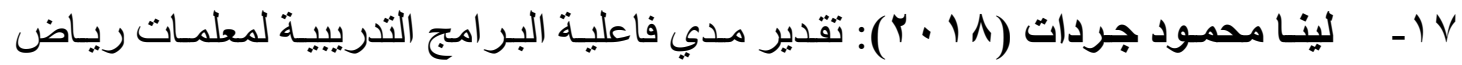

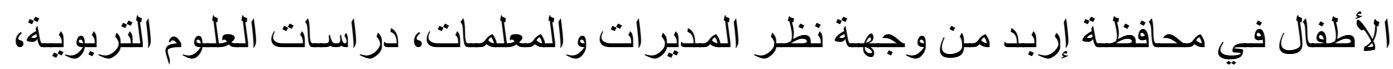
المجلد ؛( ملحق)، عمادة البحث العلمي، الجامعة الأردنية.

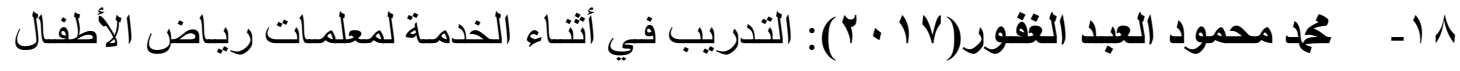

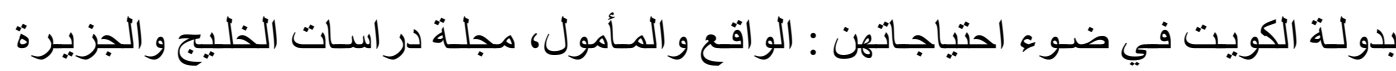

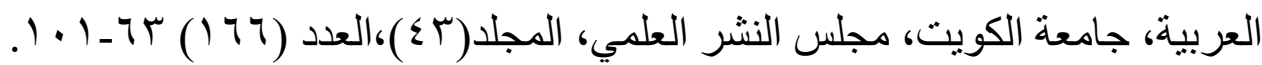

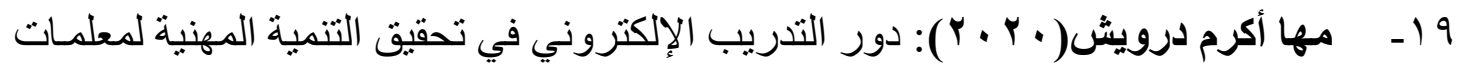

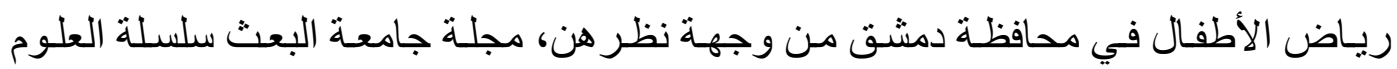
التربوية، المجلد ؟ ك،العدده، جامعة البعث، سوريا. 


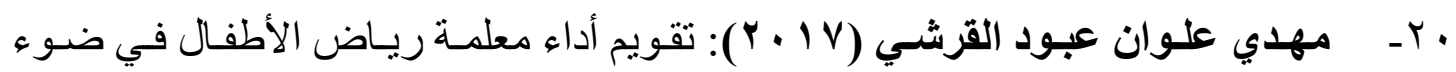

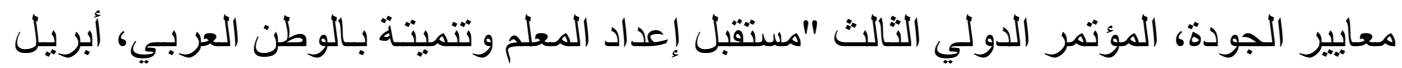
كلية التربية، جامعة ج أكتوبر بالتعاون مع ر ابطة التربويين العرب.

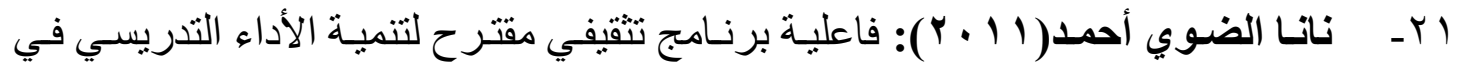

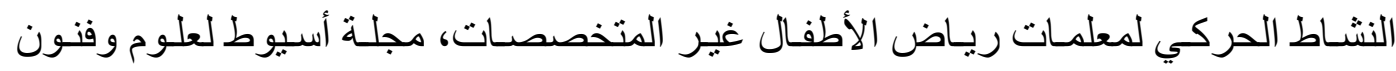

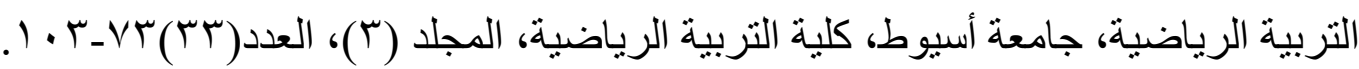

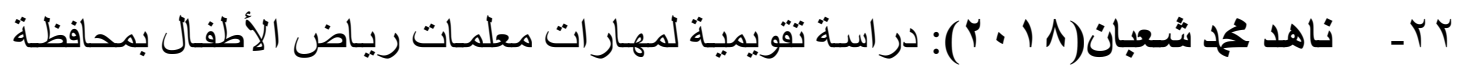
كفر الثيخ، مجلة الطفولة والتربية، المجلد العانثر، العددجب،جامعة الأسكندرية.

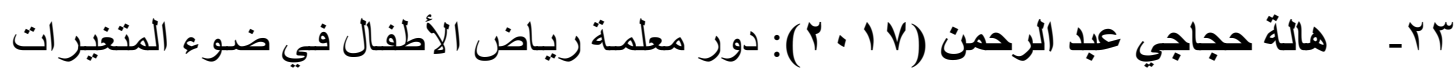
المعاصرة،ط ( امكتبة المتنبي.

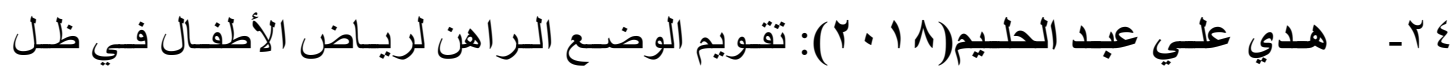

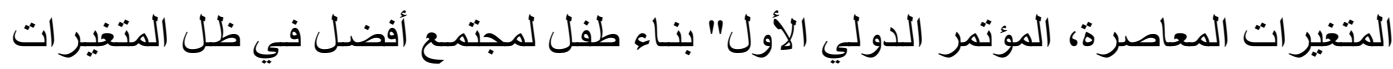
المعاصرة"، فبر اير، جامعة أسيوط.

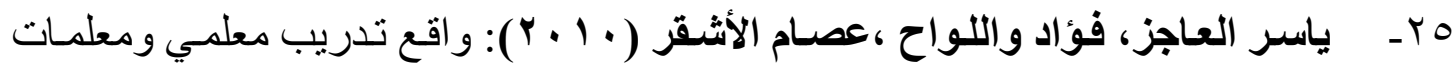

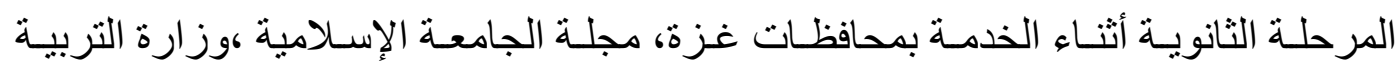

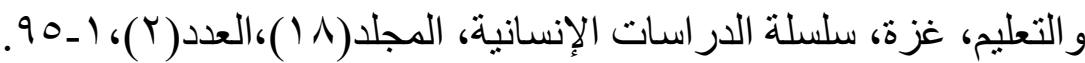
ثانياً ــ المراجع الأجنبية:

1-Bauml,m.(2011):We Learning All About that in College, The Role of Teacher Preparation in Novice Kindergarten/Primary Teachers Practice, Journal of Early Childhood Teacher Education ,32(3),p225-239.

2-Bayrakci,M.(2019): In-Service Teacher Training in Japan and Turkey ,a Comparative Analysis of Institutions and Practices, Australian Journal of Teacher Education ,Volume 34,issue 1.

3-Bodenmann, G., Perrez, M., Schar, M,\& Trepp, A (2014): Klassische Lerntheorien, Ihre Anwendung in Eriziehung and Psychotherapie ,Bern, Huber. 
4-Bressoux ,P,\& Kramarz ,F,\& Prost,C (2018):”'Teachers Training,Class Size and Students Outcomes ,Learning from Administrative Forecasting Mistakes," IZA Discussion Papers 3871, Institute for the Study of Labor (IZA).

5-Commons (2010):Training of Teacher, Children,Schools and Familles Committee,Vol.1,9 February,London,the Stationery Office Limited.

6-Demir,R,Ozturk ,N \& Dokme,I (2011): The views of the teachers taking in-service training about alternative measurement and evaluation techniques, The sample of primary school teachers, Procedia-Social and Behavioral Sciences,15,p2347-2352.

7-Guang,L,Donald, A \& Myers,K(2019): Kindergarten teachers professional training and their social status in Korea, Journal of Early Childhood Teacher Education,V(30),N(3)p 263-271.

8-Lai,C \& Wong, S (2012): Administratore Perceptions of Early Childhood Teacher Training in Hong Kong, An Exploratory Study, LA106171,1-7. Available at :

http//www.aare.edu.au/06pap/1ai06171.pdf

9-Pamela, L (2016): Early Childhood professional Development and classroom quality in preschool classrooms,(MS Oklahoma State University),p58,AAT 1433559.

10-Pineda,P, Ucar, X, Moreno, V \& Belvis, E (2011): Evaluation of Teachers Continuing Training in the Early Childhood Education Sector in Spain,Teacher Development ,15(2),p205-2018.

11-Wendy R (2016): Teacher Training in England and Wales ,Past ,Present and Future Perspective, Education Research and Perspective Vol.33,No.2. 